\title{
Modeling the global radiative effect of brown carbon: a potentially larger heating source in the tropical free troposphere than black carbon
}

\author{
Aoxing Zhang ${ }^{1}$, Yuhang Wang ${ }^{1}$, Yuzhong Zhang ${ }^{1, \mathrm{a}}$, Rodney J. Weber ${ }^{1}$, Yongjia Song ${ }^{1}$, Ziming Ke ${ }^{1, \mathrm{~b}}$, and Yufei Zou ${ }^{1, \mathrm{c}}$ \\ ${ }^{1}$ School of Earth and Atmospheric Sciences, Georgia Institute of Technology, Atlanta, GA 30332, USA \\ a now at: School of Engineering, Westlake University, Hangzhou, Zhejiang, 310024, China \\ ${ }^{b}$ now at: Department of Atmospheric Science, Texas A\&M University, College Station, TX 77843, USA \\ ${ }^{c}$ now at: Atmospheric Sciences and Global Change Division, Pacific Northwest National Laboratory, \\ Richland, WA 99354, USA
}

Correspondence: Yuhang Wang (yuhang.wang@eas.gatech.edu)

Received: 21 June 2019 - Discussion started: 2 July 2019

Revised: 21 December 2019 - Accepted: 23 January 2020 - Published: 20 February 2020

\begin{abstract}
Carbonaceous aerosols significantly affect global radiative forcing and climate through absorption and the scattering of sunlight. Black carbon (BC) and brown carbon $(\mathrm{BrC})$ are light-absorbing carbonaceous aerosols. The direct radiative effect (DRE) of $\mathrm{BrC}$ is uncertain. A recent study suggests that $\mathrm{BrC}$ absorption is comparable to $\mathrm{BC}$ in the upper troposphere over biomass burning regions and that the resulting radiative heating tends to stabilize the atmosphere. Yet current climate models do not include proper physical and chemical treatments of $\mathrm{BrC}$. In this study, we derived a $\mathrm{BrC}$ global biomass burning emission inventory on the basis of the Global Fire Emissions Database version 4 (GFED4), developed a module to simulate the light absorption of $\mathrm{BrC}$ in the Community Atmosphere Model version 5 (CAM5) of the Community Earth System Model (CESM), and investigated the photobleaching effect and convective transport of $\mathrm{BrC}$ on the basis of Studies of Emissions, Atmospheric Composition, Clouds and Climate Coupling by Regional Surveys (SEAC4RS) and Deep Convective Clouds and Chemistry Project (DC3) measurements. The model simulations of BC were also evaluated using HIAPER (HighPerformance Instrumented Airborne Platform for Environmental Research) Pole-to-Pole Observations (HIPPO) measurements. We found that globally $\mathrm{BrC}$ is a significant $\mathrm{ab}-$ sorber, the DRE of which is $0.10 \mathrm{~W} \mathrm{~m}^{-2}$, more than $25 \%$ of BC DRE $\left(+0.39 \mathrm{~W} \mathrm{~m}^{-2}\right)$. Most significantly, model results indicated that $\mathrm{BrC}$ atmospheric heating in the tropical mid and upper troposphere is larger than that of $\mathrm{BC}$. The source of
\end{abstract}

tropical $\mathrm{BrC}$ is mainly from wildfires, which are more prevalent in the tropical regions than higher latitudes and release much more $\mathrm{BrC}$ relative to $\mathrm{BC}$ than industrial sources. While $\mathrm{BC}$ atmospheric heating is skewed towards the northern midlatitude lower atmosphere, $\mathrm{BrC}$ heating is more centered in the tropical free troposphere. A possible mechanism for the enhanced convective transport of $\mathrm{BrC}$ is that hydrophobic high molecular weight $\mathrm{BrC}$ becomes a larger fraction of the $\mathrm{BrC}$ and less easily activated in a cloud as the aerosol ages. The contribution of $\mathrm{BrC}$ heating to the Hadley circulation and latitudinal expansion of the tropics is likely comparable to $\mathrm{BC}$ heating.

\section{Introduction}

Carbonaceous aerosols, including black carbon (BC) and organic carbon (OC), are important factors in global atmospheric radiative forcing. $\mathrm{BC}$ warms the atmosphere by directly absorbing solar radiation (Bond et al., 2013). OC used to be thought to cool the atmosphere due to its lightscattering properties. However, some OC, known as "brown carbon" (BrC), absorbs visible light with a wavelength dependence; the efficiency increases rapidly with decreasing wavelength (Hecobian et al., 2010; Kirchstetter and Thatcher, 2012; Kirchstetter et al., 2004; Yang et al., 2009). 
The primary source of $\mathrm{BrC}$ is the incomplete combustion of biomass and biofuel (Chakrabarty et al., 2010; Feng et al., 2013; Desyaterik et al., 2013; Washenfelder et al., 2015). There is evidence that $\mathrm{BrC}$ is also associated with fossil fuel combustion and urban emissions (Zhang et al., 2011; Costabile et al., 2017; Yan et al., 2017; Xie et al., 2017). Secondary $\mathrm{BrC}$ is mainly produced from the photo-oxidation of volatile organic compounds (VOCs), such as nitrophenols and aromatic carbonyls (Jacobson, 1999; Nakayama et al., 2010, 2013), monoterpenes (Laskin et al., 2014), and methylglyoxal (Sareen et al., 2013). Secondary BrC also comes from aqueous-phase reactions in droplets (Updyke et al., 2012; Nguyen et al., 2012) and homogenous and heterogenous reactions of catechol (Pillar et al., 2014; Pillar and Guzman, 2017; Magalhães et al., 2017) and phenolic compounds (Yu et al., 2016; Lavi et al., 2017; Smith et al., 2016). BrC from biomass burning contributes more to light absorption than the other sources (Chakrabarty et al., 2010; Saleh et al., 2014; Kirchstetter and Thatcher, 2012; McMeeking, 2008). Factor analysis of water-soluble organic carbon (WSOC) over the southeastern United States averaged for one year (Hecobian et al., 2010) attributed $\sim 50 \%$ of solar absorption at $365 \mathrm{~nm}$ to biomass burning emissions, $20 \%-30 \%$ to secondary organic carbon and $\sim 10 \%$ to primary urban emissions (mobile sources).

Alexander et al. (2008) analyzed the radiative effects of aerosols in the outflow region of East Asia and found that wood smoke BrC accounted for $14 \%$ of total aerosol absorption. Liu et al. (2014) found a $\sim 20 \%$ reduction of aerosol cooling from $\mathrm{BrC}$ absorption at the top of the atmosphere on the basis of measured $\mathrm{BrC}$ vertical profiles. However, current observations do not provide enough constraints on the global $\mathrm{BrC}$ radiative forcing (Schuster et al., 2016a, b).

Global models have been applied to estimate direct radiative forcing (DRF) and direct radiative effects (DREs) of BrC. Aerosol DRE represents the difference of the radiative budget with and without aerosols, and DRF represents the difference of DRE between the present day and preindustrial times (Heald et al., 2014). The study by Feng et al. (2013) suggested a $+0.04-0.11 \mathrm{~W} \mathrm{~m}^{-2}$ warming effect at the top of the atmosphere due to the absorption of $\mathrm{BrC}$ and attributed $19 \%$ of anthropogenic aerosol absorption to $\mathrm{BrC}$. $X$. Wang et al. (2014) estimated the global DRF of +0.11 and $+0.21 \mathrm{~W} \mathrm{~m}^{-2}$ for BrC and BC, respectively. Jo et al. (2016) estimated a BrC DRE of $+0.11 \mathrm{~W} \mathrm{~m}^{-2}$. Lin et al. (2014) estimated a BrC DRE of $+0.22-0.57 \mathrm{~W} \mathrm{~m}^{-2}$, which accounted for $27 \%-70 \%$ of the $\mathrm{BC}$ absorption in their model. Park et al. (2010) modeled BrC over East Asia and calculated a DRE of $+0.05 \mathrm{~W} \mathrm{~m}^{-2}$ at the top of the atmosphere. Brown et al. (2018) estimated a BrC DRE of $+0.13 \pm 0.01 \mathrm{~W} \mathrm{~m}^{-2}$ and $0.01 \pm 0.04 \mathrm{~W} \mathrm{~m}^{-2}$ from $\mathrm{BrC}$ aerosol-cloud interaction. Saleh et al. (2015) estimated a BrC DRE of $0.22 \mathrm{~W} \mathrm{~m}^{-2}$ when $\mathrm{BrC}$ is externally mixed with $\mathrm{BC}$ and $0.12 \mathrm{~W} \mathrm{~m}^{-2}$ when $\mathrm{BrC}$ is internally mixed with $\mathrm{BC}$. All of these model estimations of BrC DRE and DRF treated BrC similar to BC, where properties were invariant with atmospheric processing or aging.

Laboratory and field studies showed a reduction of $\mathrm{BrC}$ absorption when exposed to light, which is usually referred to as "photobleaching" (Zhao et al., 2015). A recent global model simulation (Wang et al., 2018) included this effect, constrained with BrC absorption measurements in the Deep Convective Clouds and Chemistry Project (DC3) and Studies of Emissions, Atmospheric Composition, Clouds and Climate Coupling by Regional Surveys (SEAC4RS), resulting in a large reduction of global $\mathrm{BrC}$ DRE to $+0.048 \mathrm{~W} \mathrm{~m}^{-2}$ compared to previous estimates from the studies listed above. Brown et al. (2018) developed a BrC module in the CESM and showed a reduction of $\mathrm{BrC}$ DRE to $0.06 \pm 0.008 \mathrm{~W} \mathrm{~m}^{-2}$ because of photobleaching. Other effects of atmospheric processing have not yet been in $\mathrm{BrC}$ global modeling. Results from the Deep Convective Clouds and Chemistry Project found high concentrations of $\mathrm{BrC}$ in the continental upper tropospheric due to convective transport, suggesting more efficient atmospheric vertical transport of $\mathrm{BrC}$ than previously assumed (Zhang et al., 2017). In this study, we developed and implemented a $\mathrm{BrC}$ module in the Community Earth System Model (CESM) to assess the effects of BrC DRE. Here, we include these effects and make use of the aircraft measurements of BrC absorption profiles from the DC3 and SEAC4RS campaigns to evaluate the model formulation and simulation results. The global $\mathrm{BrC}$ emissions from biomass burning, biofuel emissions and secondary formation were included. We tested the sensitivity of the photobleaching effect and the deep-convective transport of $\mathrm{BrC}$ to its DRE and estimated the global DRE. Model simulation results, without considering the differential convective transport and $\mathrm{BC}$ and $\mathrm{BrC}$, are compared to previous studies. This is the first attempt to comprehensively analyze how convective transport and photobleaching affect global atmospheric heating by $\mathrm{BrC}$ absorption relative to $\mathrm{BC}$.

\section{Model description}

\subsection{The CESM model}

We developed the brown carbon simulation based on the Community Earth System Model version 1.2.2 and its atmospheric component, the Community Atmosphere Model version 5 (CAM5) (Neale et al., 2010). The CAM5 model has a comprehensive mechanism for aerosols and aerosol-cloud interaction (Liu et al., 2012; Ghan et al., 2012; Gettelman et al., 2010). The CAM5 radiation scheme is the Rapid Radiative Transfer Method for Global Climate Models (GCMs) (RRTMG), which provides an accurate method for radiative flux calculation (Iacono et al., 2008; Mlawer et al., 1997). The atmospheric-chemistry module, turbulence scheme, convection scheme and cloud physics are coupled in the model (Zhang and McFarlane, 1995; Bretherton and Park, 2009; 
Park and Bretherton, 2009; Richter and Rasch, 2008; Morrison and Gettelman, 2008). We used a three-mode version of the modal aerosol model (MAM3) for aerosol modeling in CAM5. The three modes are the Aitken, accumulation and coarse modes (Neale et al., 2010). In our BrC simulations, we used CAM5 with a spatial resolution of $1.9^{\circ} \times 2.5^{\circ}$. The wet scavenging scheme of aerosols in CAM5 includes belowcloud scavenging and in-cloud scavenging, which was found to have a high bias (Wang et al., 2011; Liu et al., 2012; Yu et al., 2019). For the simulations used to compare with field observations, we nudged the CAM5 meteorological field (temperature, humidity, wind, surface pressure and heat) to the same meteorological year, month and day as the observations using Goddard Earth Observing System (GEOS)-5.2.0 meteorological data products (Rienecker et al., 2008) every $6 \mathrm{~h}$ in order to evaluate the model simulations with $\mathrm{BrC}$ observations (Ma et al., 2013; Chipperfield, 2006). We also conducted 5-year free-running model simulations using the climatology of 2010 to analyze the climate response to $\mathrm{BrC}$ and BC heating. The spin-up time is 3 months in the nudged CAM5 simulations and 1 year in the free-running simulations.

\subsection{Emissions}

We derived global $\mathrm{BrC}$ emissions from biomass burning, biofuel and secondary formation. As with Brown et al. (2018), we used the parameterization by Saleh et al. (2014) for biomass and biofuel burning, in which emitted $\mathrm{BrC}$ absorption is a function of the $\mathrm{BC} / \mathrm{OA}$ (organic aerosol) emission ratio. We included secondary aerosols from the oxidation of aromatics as the major source of secondary $\mathrm{BrC}$ (Hecobian et al., 2010; Sareen et al., 2013; Lin et al., 2015). Secondary $\mathrm{BrC}$ produced from aromatic oxidation absorbs more solar radiation in high- $\mathrm{NO}_{x}$ conditions (Laskin et al., 2015; Lin et al., 2015; Liu et al., 2012; Nakayama et al., 2010, 2013; Yu et al., 2014; Zhong and Jang, 2011). We did not consider the $\mathrm{NO}_{x}$ dependence of secondary $\mathrm{BrC}$ in this study. More details will be described in Sect. 3 .

The biomass burning emissions we used are from the Global Fire Emission Database version 4 (GFED4) including small fires (GFED4s) (Giglio et al., 2013; Randerson et al., 2012). It contains global burned area distribution and biomass burning emission factors of related aerosols and gas species for different fire types, with a spatial resolution of $0.25^{\circ} \times 0.25^{\circ}$. In CAM5, we aggregated it to a spatial resolution to $1.9^{\circ} \times 2.5^{\circ}$ and used GFED daily emission and diurnal cycle factors. The different emission factors for tropical forests, temperate forests, boreal forests, savannas, agriculture waste and peat burning are based on Akagi et al. (2011). Fire emissions can reach high altitudes (e.g., Neale et al., 2010). We used an observation-constrained global fire plume rise dataset in which MODIS fire hotspot and fire radiance power data were used in a 1-D fire plume rise model, and the resulting fire plume distribution is in good agreement with

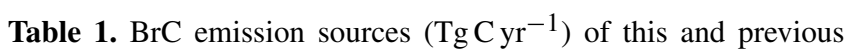
studies.

\begin{tabular}{lrrr}
\hline & $\begin{array}{r}\text { This } \\
\text { work }\end{array}$ & $\begin{array}{r}\text { Jo et } \\
\text { al. (2016) }\end{array}$ & $\begin{array}{r}\text { Wang et } \\
\text { al. }(2014)\end{array}$ \\
\hline Primary biomass burning source & 3.6 & $3.0 \pm 1.7$ & 8 for primary \\
Primary biofuel source & 3.1 & $3.0 \pm 1.3$ & sources \\
Secondary formation & 4.1 & 5.7 & 3.2 \\
\hline
\end{tabular}

the Multi-angle Imaging SpectroRadiometer (MISR) observations (Ke, 2020). Biomass burning emissions have high uncertainties caused by burned area, emission factors, fuel loads and combustion completeness factors (Akagi et al., 2011; Giglio et al., 2013), and the complex interactions between fire, terrestrial ecosystem and climate systems amplify these uncertainties (Zou et al., 2019).

Anthropogenic emissions are from the Intergovernmental Panel on Climate Change (IPCC) Fifth Assessment Report (AR5) emission dataset (Lamarque et al., 2010), and BC and OC emissions are updated based on the emission inventory of 2000 (Bond et al., 2007; Junker and Liousse, 2008). We increased anthropogenic emissions in China by $50 \%$ according to Zhang et al. (2009). For the Arctic region $\left(>66^{\circ} \mathrm{N}\right)$, we used the Evaluating the Climate and Air Quality Impacts of Short-lived Pollutants (ECLIPSE) emission dataset, which includes an improvement for the Arctic BC emissions (Stohl et al., 2013; Klimont et al., 2015).

For the optical properties of $\mathrm{BC}$, we used 10 and $8.1 \mathrm{~m}^{2} \mathrm{~g}^{-1}$ for $345-442 \mathrm{~nm}$ and $442-625 \mathrm{~nm}$, respectively, as the MAE values of BC (Knox et al., 2009; Bond and Bergstrom, 2006). The MAE values are lower than the estimation by Bond et al. (2013) $\left(11 \mathrm{~m}^{2} \mathrm{~g}^{-1}\right)$ and Jacobson (2016) $\left(16 \mathrm{~m}^{2} \mathrm{~g}^{-1}\right.$ including high-relative-humidity conditions) and are higher than the estimation by Schulz et al. (2006) $\left(7.9 \pm 1.9 \mathrm{~m}^{2} \mathrm{~g}^{-1}\right)$. MAM3 assumes that primary carbon is internally mixed with secondary aerosols in the accumulation mode.

\section{Brown carbon module}

\subsection{BrC optical property and photobleaching}

$\mathrm{BrC}$ absorption depends on its Mass Absorption Efficiency (MAE), which is the ratio of light absorption in the wavelength $\lambda$ to $\mathrm{BrC}$ mass concentration $\left(\mathrm{m}^{2} \mathrm{~g}^{-1}\right)$.

$\operatorname{MAE}_{\mathrm{BrC}}(\lambda)=\frac{A(\lambda)}{C_{\mathrm{BrC}}}$,

where $A(\lambda)$ represents the absorption of $\mathrm{BrC}$ at the wavelength of $\lambda\left(\mathrm{m}^{-1}\right)$ and $C_{\mathrm{BrC}}$ is the mass concentration of $\mathrm{BrC}$ $\left(\mathrm{g} \mathrm{m}^{-3}\right)$.

Similar to Jo et al. (2016), we used a constant MAE value for primary $\mathrm{BrC}, 1.0 \mathrm{~m}^{2} \mathrm{~g}^{-1}$ at $550 \mathrm{~nm}$ (McMeeking, 2008), 

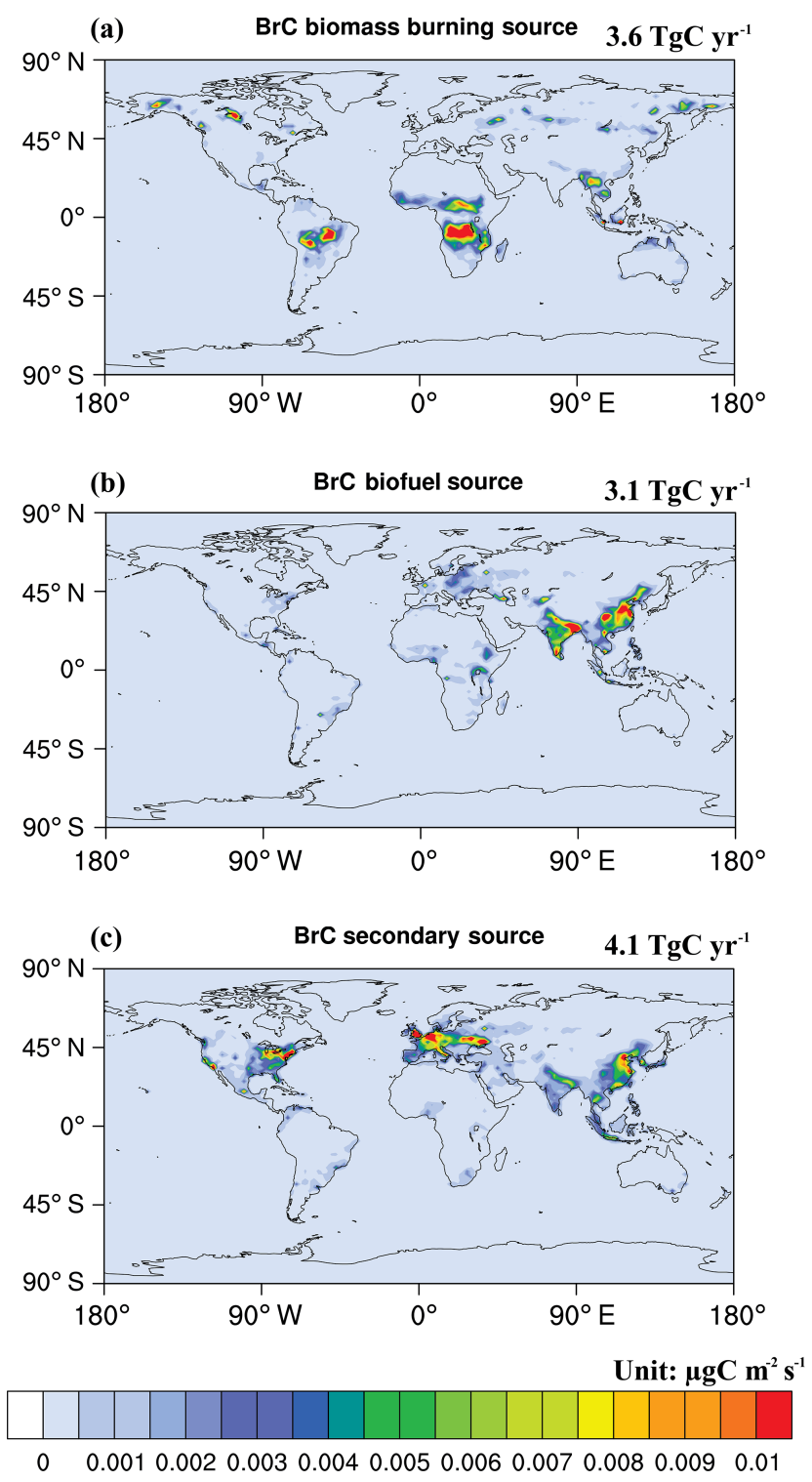

Figure 1. Spatial distributions of global emissions of $\mathrm{BrC}$ from biomass burning (a), anthropogenic biofuel combustion (b) and secondary formation (c) in 2010 . The unit is $\mu \mathrm{g} \mathrm{C} \mathrm{m}^{-2} \mathrm{~s}^{-1}$. The total emission is 3.6, 3.1 and $4.1 \mathrm{Tg} \mathrm{C} \mathrm{yr}^{-1}$ for biomass burning, biofuel and secondary formation, respectively.

and we used an MAE value of $0.19 \mathrm{~m}^{2} \mathrm{~g}^{-1}$ at $550 \mathrm{~nm}$ for secondary BrC based on the work by Nakayama et al. (2010). There are other MAE estimates in experiments such as 3.6$4.1 \mathrm{~m}^{2} \mathrm{~g}^{-1}$ (Alexander et al., 2008) and $0.58-0.64 \mathrm{~m}^{2} \mathrm{~g}^{-1}$ (Hecobian et al., 2010) and model-specified values such as $0.35 \mathrm{~m}^{2} \mathrm{~g}^{-1}$ by Wang et al. (2018). The MAE value may also change in different seasons (Cheng et al., 2011). At present, there are not enough observations to specify variable MAE values in the model. The MAE value at the other wavelengths was calculated using the following function (Bond

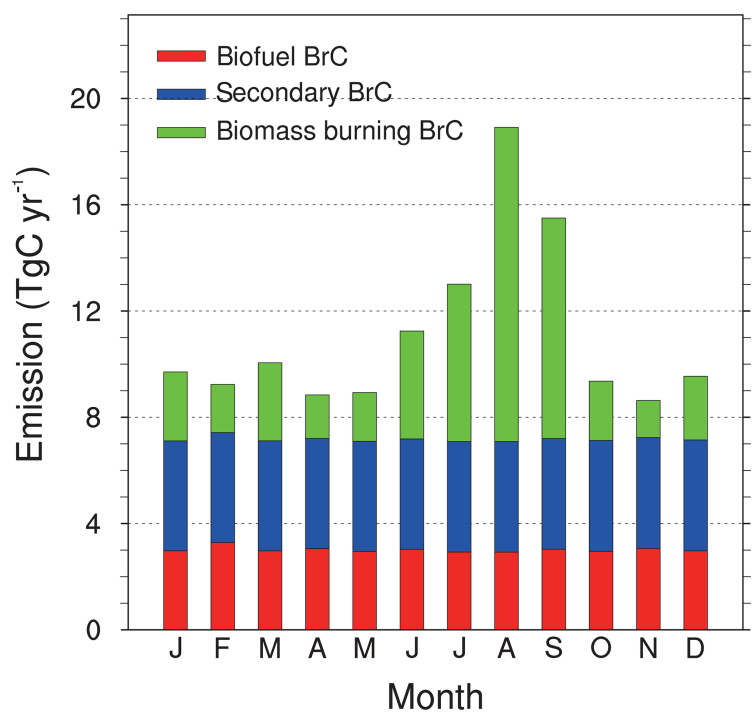

Figure 2. Monthly mean global $\mathrm{BrC}$ emission rates $\left(\mathrm{Tg} \mathrm{C} \mathrm{yr}^{-1}\right)$ in 2010. Green, blue and red bars represent the emissions from biomass burning, biofuel combustion and secondary $\mathrm{BrC}$ formation, respectively.

and Bergstrom, 2006):

$\operatorname{MAE}(\lambda)=\operatorname{MAE}\left(\lambda_{0}\right) *\left(\lambda_{0} / \lambda\right)^{\mathrm{AAE}}$,

where AAE is the absorption Angström exponent and $\lambda_{0}$ is 550 and $365 \mathrm{~nm}$ for primary and secondary $\mathrm{BrC}$, respectively. We used AAE $=5.0$ for $\lambda<2 \mu \mathrm{m}$ (Jo et al., 2016; Kirchstetter and Thatcher, 2012). BrC AAE varies depending on its source and the wavelength used (Kirchstetter and Thatcher, 2012; Liu et al., 2014). Jo et al. (2016) found BrC/BC ratio decreases when the $\mathrm{BrC} \mathrm{AAE}$ increases from 5 to 6.19; Saleh et al. (2014) also found that the BC/OA ratio is negatively related to $\mathrm{BrC} \mathrm{AAE}$ and positively related to $\mathrm{BrC}$ absorption. Therefore, the variation of $\mathrm{BrC}$ AAE leads to additional uncertainty of the $\mathrm{BrC}$ simulation. The imaginary part of the refractive index for $\mathrm{BrC}$ is estimated using the following equation (Liu et al., 2013):

$k_{\mathrm{BrC}, \lambda}=k_{\mathrm{OA}, \lambda} * \frac{c_{\mathrm{OA}}}{c_{\mathrm{BrC}}}=\frac{\rho \lambda \cdot A(\lambda)}{4 \pi \cdot c_{\mathrm{BrC}}}=\frac{\rho \lambda \cdot \operatorname{MAE}(\lambda)}{4 \pi}$,

where $\rho$ is particle density $\left(\mathrm{g} \mathrm{m}^{-3}\right), A(\lambda)$ is the light absorption at wavelength $\lambda$ and $c$ is mass concentration.

The estimated $k_{\mathrm{BrC}}$ value is 0.045 at $550 \mathrm{~nm}$ for primary $\mathrm{BrC}$ and 0.043 at $365 \mathrm{~nm}$ for secondary $\mathrm{BrC}$, respectively.

There is observational evidence that both primary and secondary $\mathrm{BrC}$ are affected by photochemical aging (or bleaching), which reduces $\mathrm{BrC}$ light absorption when exposed to light (Forrister et al., 2015; Sareen et al., 2013; Lee et al., 2014; Zhong and Jang, 2011; Wong et al., 2017, 2019). Previous modeling of the $\mathrm{BrC}$ photobleaching effect by Wang et al. (2018) and Brown et al. (2018) applied a $1 \mathrm{~d}$ e-folding time for $\mathrm{BrC}$ before reaching a threshold of $25 \%$ of the 
original $\mathrm{BrC}$ absorption. Our approach to $\mathrm{BrC}$ photobleaching considers different bleaching effects depending on $\mathrm{BrC}$ source. We specify a decay half-life of $12 \mathrm{~h}$ when light is present for primary biomass and biofuel $\mathrm{BrC}$ in the daytime until $6 \%$ is left and no further photobleaching occurs (Forrister et al., 2015) due to stable high-molecular-weight chromophores (Di Lorenzo and Young, 2015; Di Lorenzo et al., 2017; Wong et al., 2017, 2019). Different components of secondary organic aerosol (SOA) have different photobleaching lifetimes. Aromatic SOA has a half-life of $12-24 \mathrm{~h}$ (Liu et al., 2016; Lee et al., 2014; Zhong and Jang, 2011), and limonene SOA has a half-life of $<0.5 \mathrm{~h}$ (Lee et al., 2014). Methylglyoxal SOA has a half-life of $90 \mathrm{~min}$ (Zhao et al., 2015; Wong et al., 2017). Therefore, the half-life for secondary aromatic $\mathrm{BrC}$ is specified at $12 \mathrm{~h}$ in daytime until it is completely removed (Liu et al., 2016). The other secondary BrCs that have shorter lifetimes contribute little to global radiative forcing and are not included in the model.

The analysis of aircraft $\mathrm{BrC}$ observations by Zhang et al. (2017) showed that $\mathrm{BrC}$ transported by deep convection plays a significant role in the radiative heating of the upper troposphere and that $\mathrm{BrC}$ warming is about one third of $\mathrm{BC}$ warming at the tropopause. The standard model simulations show a large low bias of $\mathrm{BrC}$ in the upper troposphere compared to the observations by Zhang et al. (2017). In addition, in-cloud heterogeneous $\mathrm{BrC}$ production is another possible reason for the high level of $\mathrm{BrC}$ in the upper troposphere. A fraction of biomass burning $\mathrm{BrC}$ from heterogeneous oxidation by ozone will stay free from photobleaching, and $\mathrm{BrC}$ from heterogeneous oxidations by $\mathrm{OH}$ has a long lifetime of days (Browne et al., 2019). Therefore, we conducted sensitivity simulations of $\mathrm{BrC}$ to investigate the effects of photobleaching and wet scavenging during deep convection.

One important finding by Zhang et al. (2017) is that wet scavenging of $\mathrm{BrC}$ during convection differs from $\mathrm{BC}$ and $\mathrm{OC}$. Therefore, $\mathrm{BrC}$ is simulated using a different tracer from OC in this work unlike Brown et al. (2018). The BrC property of interest is absorption, and we assume that the tracer's optical property is light absorption only (no scattering). Consequently, there is no double counting of OC scattering. However, it should be noted that $\mathrm{BrC}$ is a class of organic aerosols that both scatter and absorb light. We analyzed in this study the effect of $\mathrm{BrC}$ light absorption. The model simulation of OC mass and scattering was not affected by the simulation of a $\mathrm{BrC}$ tracer that only absorbs light. In the following analysis, the DRE from $\mathrm{BrC}$ is for light absorption only such that it represents the DRE of the OC absorption and can be compared to the DRE of the $\mathrm{BC}$ absorption.

\subsection{BrC emissions}

We assumed that $\mathrm{BrC}$ is emitted in the accumulation mode (Liu et al., 2013). Sources of the more stable forms of BrC include primary emissions of biomass burning and biofuel as well as secondary formation from aromatic oxidation. Simi-

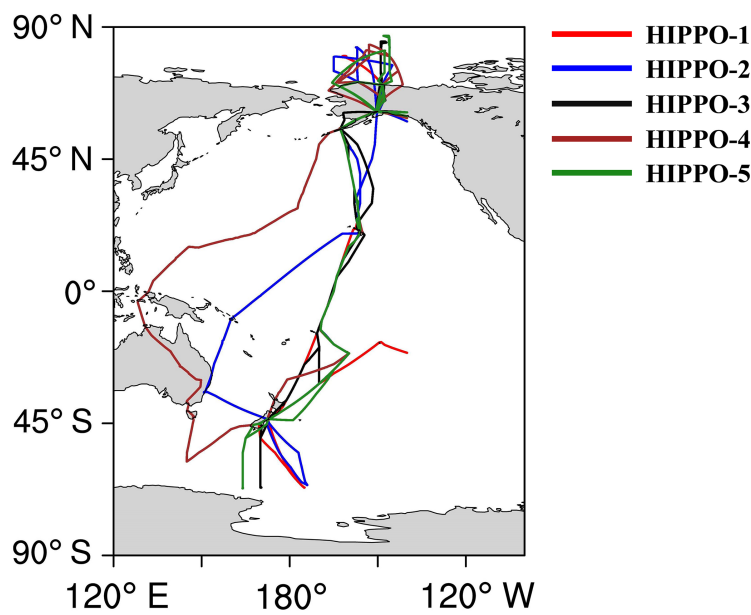

Figure 3. Flight track of the five HIPPO missions. Colored lines in red, blue, black, brown and green represent flight track of HIPPO-1 to HIPPO-5, respectively. Flights over continental North America east of $140^{\circ} \mathrm{W}$ were not included in this study.

lar to previous model approaches (Wang et al., 2018; Brown et al., 2018), biomass burning $\mathrm{BrC}$ emissions were parameterized as a function of the BC-to-OA ratio of the emissions (Saleh et al., 2014).

$k_{\mathrm{OA}, 550}=0.016 \log _{10}\left(\frac{E_{\mathrm{BC}}}{E_{\mathrm{OA}}}\right)+0.03925$,

where $k_{\mathrm{OA}, 550}$ is $\mathrm{OA}$ absorptivity at $550 \mathrm{~nm}$ and $E_{\mathrm{BC}}$ and $E_{\mathrm{OA}}$ are $\mathrm{BC}$ and $\mathrm{OA}$ emission rates $\left(\mathrm{g} \mathrm{m}^{-2} \mathrm{~s}^{-1}\right)$, respectively. We computed $k_{\mathrm{OA}, 550}$ in order to calculate $\mathrm{BrC}$ emissions. In the model, the absorption of the OC tracer was specified to be 0 . All OC absorption was due to the $\mathrm{BrC}$ tracer. We scaled $\mathrm{BrC}$ emissions based on $k_{\mathrm{OA}, 550}$; MAE and $\mathrm{OA}$ emissions used the following equation by Liu et al. (2013):

$E_{\mathrm{BrC}}=\frac{4 \pi k_{\mathrm{OA}, 550} \cdot E_{\mathrm{OA}}}{\rho \cdot 550 \mathrm{~nm} \cdot \mathrm{MAE}_{\mathrm{BrC}}(550 \mathrm{~nm})}$,

where $\rho$ is particle density $\left(\mathrm{g} \mathrm{m}^{-3}\right)$ and $E_{\mathrm{BrC}}$ is the BrC emission rate $\left(\mathrm{g} \mathrm{m}^{-2} \mathrm{~s}^{-1}\right)$.

Using the GFED emissions inventory, we estimated an annual average global $\mathrm{BrC}$ source from biomass burning of 3.6 $\mathrm{Tg} \mathrm{C} \mathrm{yr}^{-1}, \sim 23 \%$ of OC emissions (15.9 $\mathrm{Tg} \mathrm{C} \mathrm{yr}^{-1}$ ) and

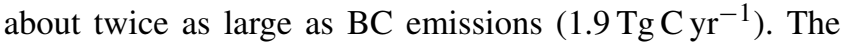
variability of the $\mathrm{BrC}$ emission rate among biomes therefore depends on the BC-to-OA emission ratios in the GFED emission inventory. Using the same equations and an average $E_{\mathrm{BC}} / E_{\mathrm{OA}}$ ratio of 0.41 (Junker and Liousse, 2008), we estimated an $E_{\mathrm{BrC}} / E_{\mathrm{OA}}$ ratio of 0.38 and an annual global $\mathrm{BrC}$ biofuel source of $3.1 \mathrm{TgC}^{-1}$ on the basis of the biofuel emission inventory by Fernandes et al. (2007). The estimates of primary $\mathrm{BrC}$ emissions are comparable to previous studies (Table 1). BrC emissions from fossil fuel combustion are not yet characterized well enough to be included in a global model (Saleh et al., 2014; Xie et al., 2017). 
(a) HIPPO

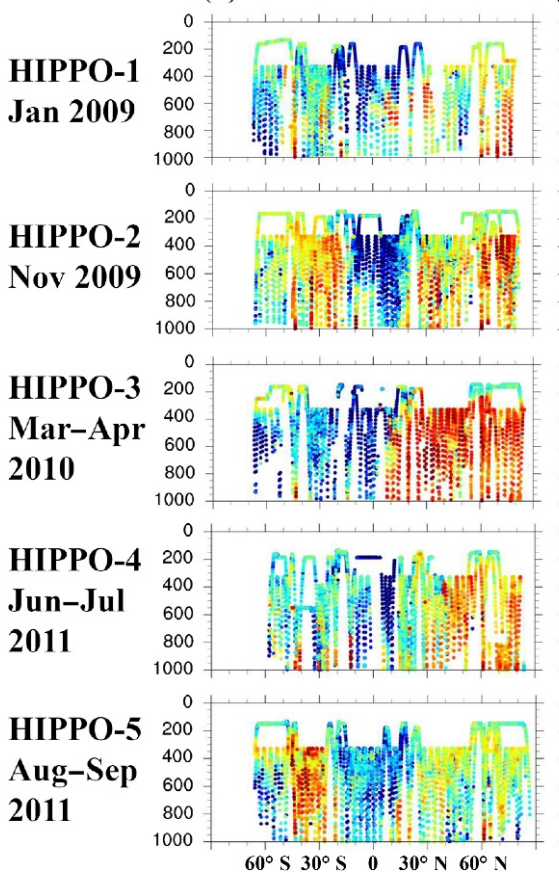

(b)

CAM5
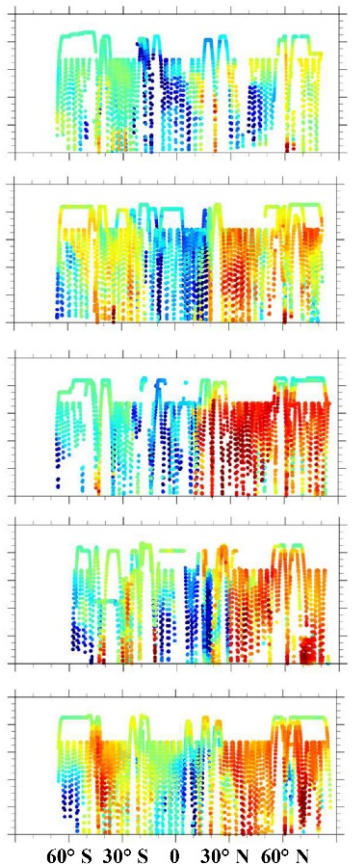

(c) CAM5_default
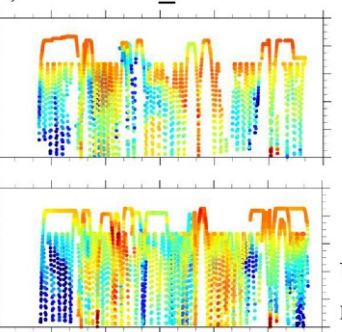

Unit: ngC kg-1
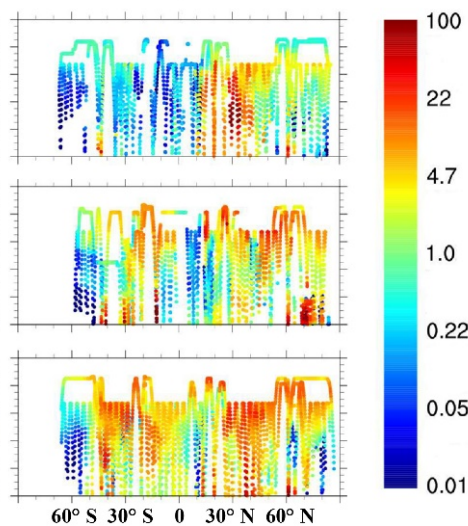

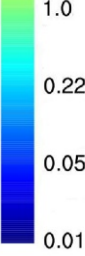

Figure 4. Comparison of HIPPO BC $\left(\mathrm{ng} \mathrm{C} \mathrm{kg}^{-1}\right)$ measurements (a), simulated BC data from the modified CAM5 model (b) and simulated BC data from the default CAM5 model (c) during HIPPO-1 to HIPPO-5. The five rows from top to bottom are HIPPO-1 (January 2009), HIPPO-2 (November 2009), HIPPO-3 (March-April 2010), HIPPO-4 (June-July 2011) and HIPPO-5 (August-September 2011), respectively. Measurement data along the flight tracks of Fig. 3 are 1 min averages. Model data are selected corresponding to the location and time of aircraft measurements.

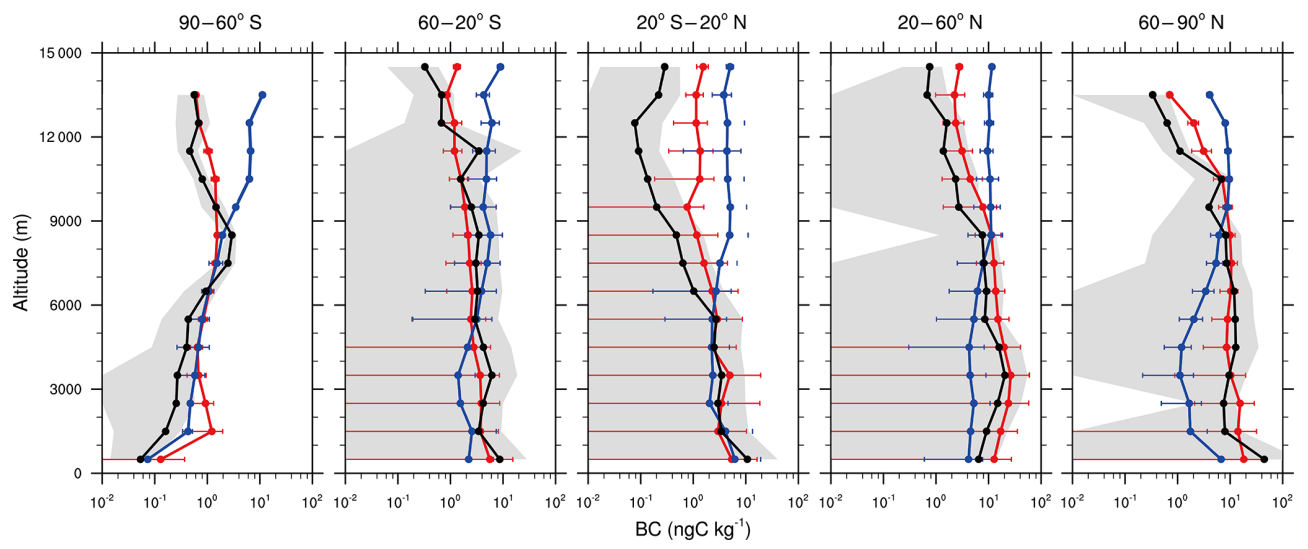

Figure 5. Comparison of observed and simulated BC vertical profiles during HIPPO missions for the latitude bins of $90-60^{\circ} \mathrm{S}, 60-20^{\circ} \mathrm{S}$, $20^{\circ} \mathrm{S}-20^{\circ} \mathrm{N}, 20-60^{\circ} \mathrm{N}$ and $60-90^{\circ} \mathrm{N}$. Black lines and shaded areas show the means and standard deviations of the observations binned in $1 \mathrm{~km}$ intervals, respectively. The colored vertical lines and horizontal bars show the means and standard deviations of the default (blue) and modified CAM5 results (red), respectively.

The major fraction of secondary $\mathrm{BrC}$ that affects atmospheric heating is formed during the oxidation of aromatics (Jacobson, 1999; Nakayama et al., 2013; Zhong et al., 2012). As in previous studies (Jo et al., 2016; Wang et al., 2014), we assumed that secondary $\mathrm{BrC}$ is from aged aromatic SOA. In the CAM5-MAM3 aerosol mechanism, the SOA mass yield for aromatic oxidation is $15 \%$ (Neale et al., 2010; Odum et al., 1997). We estimated a global secondary BrC source of 4.1 $\mathrm{TgC}^{-1} \mathrm{r}^{-1}$ in agreement with previous studies.

$\mathrm{BrC}$ emissions used in this study and the comparison to previous studies are summarized in Table 1, and the emission distribution is shown in Fig. 1. Biofuel emissions are high in China and India, and secondary $\mathrm{BrC}$ sources are also large in Europe and North America. Figure 2 shows the an- 

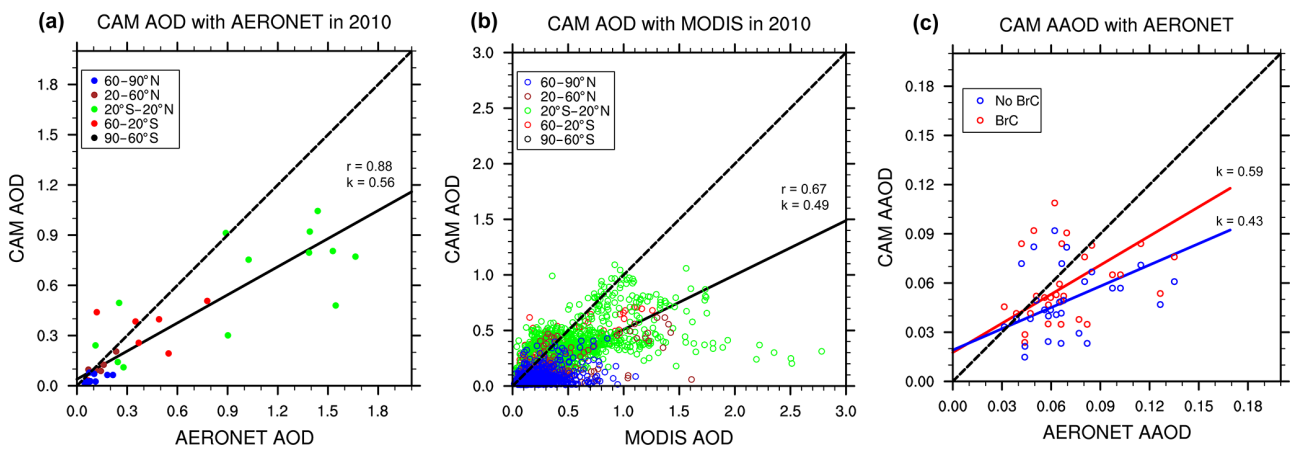

Figure 6. Comparison of monthly mean AOD and AAOD data in $550 \mathrm{~nm}$ for fire-dominated months and regions (Fig. S1a) of model simulations with the observations for (a) 2010 AERONET AOD, (b) 2010 MODIS AOD and (c) 2005-2014 AERONET AAOD. For (a) and (b), model data correspond to the same time and location of the observations. The data points in (a) and (b) are color-coded as a function of latitude. The solid line denotes a PC regression line, and the dashed line denotes the $1: 1$ reference line. For (c), monthly mean values of model data corresponding to AERONET AAOD observations are shown. The solid lines denote PC regression lines for model results with and without $\mathrm{BrC}$ absorption, and the corresponding regression slope $(k)$ values are shown. The dashed line denotes the $1: 1$ reference line.

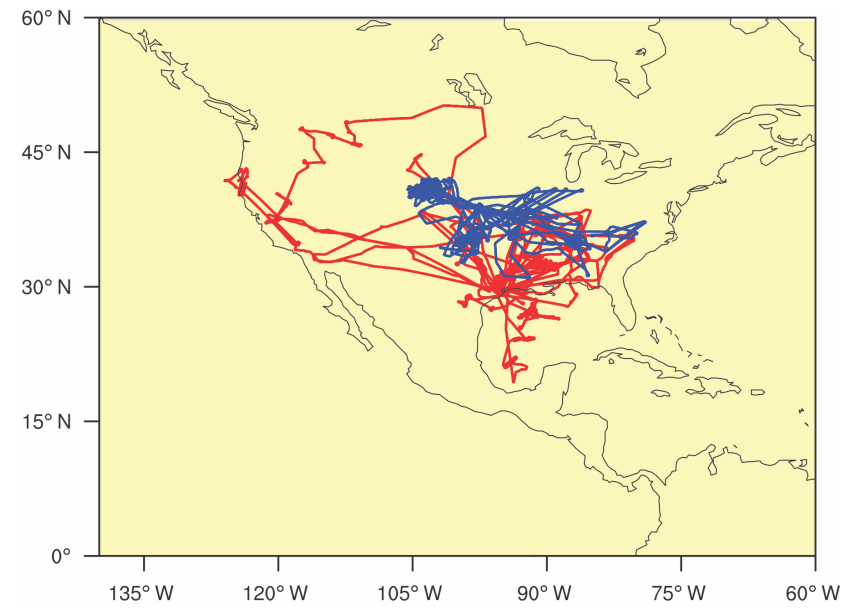

Figure 7. Flight tracks of the SEAC4RS (red) and DC3 (blue) field experiments.

nual cycle of BrC emissions in 2010. Biofuel and secondary $\mathrm{BrC}$ sources have little seasonal variation in the model, while biomass burning has significant seasonal variation. The $\mathrm{BrC}$ source is the highest in August at $18.9 \mathrm{Tg} \mathrm{C} \mathrm{yr}^{-1}$. Biomass burning emission accounts for more than $60 \%$ of the $\mathrm{BrC}$ emissions in August.

\section{Model evaluation}

\subsection{Black carbon measurements from HIPPO}

HIAPER (High-Performance Instrumented Airborne Platform for Environmental Research) Pole-to-Pole Observations (HIPPO) measured atmospheric composition approximately from the Arctic to the Antarctic over the Pacific Ocean (Wofsy, 2011). HIPPO executed five missions from January 2009 to September 2011. The flight path of each
HIPPO mission is shown in Fig. 3. Measurements over continental North America east of $140^{\circ} \mathrm{W}$ were not included in our model evaluation. BC measurements for particles with a size range of $90-600 \mathrm{~nm}$ were made from a single-particle soot photometer (SP2), and we increased measured BC data by a factor of 1.1 to account for larger-sized $\mathrm{BC}$ in the model evaluation (Schwarz et al., 2010, 2013). We make use of HIPPO BC measurements to constrain convective transport and wet scavenging.

Wet scavenging is uncertain in the 3-D global modeling of BC (Schwarz et al., 2010; Liu et al., 2011). Wang et al. (2013) tested the sensitivities of different physical mechanisms and found a high sensitivity of $\mathrm{BC}$ simulations to convective transport and wet removal. A comparison of CAM5 BC simulations with HIPPO observations in Fig. 4 shows large overestimates of $\mathrm{BC}$ in the tropics and the upper troposphere. Since the emissions of BC are from the surface, the model high biases in these regions suggest insufficient wet scavenging during convection. Wang et al. (2014) updated the model wet scavenging by scavenging hydrophobic aerosols in convective updrafts and scavenging hydrophilic aerosols from cold clouds. In all simulations of this study, we increased interstitial BC scavenging by a factor of 5 to increase wet scavenging and reduced stratiform liquidcontaining clouds based on model evaluations using HIPPO observations. The high biases above $300 \mathrm{hPa}$ at mid and high latitudes persisted particularly for HIPPO-1 in January 2009 and HIPPO-2 in November 2009. In winter, the simulated high $\mathrm{BC}$ concentrations were above the tropopause level at mid and high latitudes, indicating that convective transport reached too high an altitude. We therefore limited deepconvection mass transport to an altitude of $50 \mathrm{hPa}$ below the model estimated tropopause, after which the high biases at mid and high latitudes above $200 \mathrm{hPa}$ were corrected. During HIPPO-3 in March-April 2010, model-simulated freetropospheric $\mathrm{BC}$ at northern mid and high latitudes was much 
lower than the observations, suggesting excessive scavenging in the model. We reduced cloud-born $\mathrm{BC}$ scavenging to $10 \%$ when cloud ice is present and to $50 \%$ for the other conditions, which improved the model simulations of freetropospheric BC at mid and high latitudes in HIPPO-3 (and HIPPO-2). The modification slightly worsened the model high bias at northern mid and high latitudes in the summer for HIPPO-5 in August-September 2011 and to a lesser extent for HIPPO-4 in June-July 2011. Figure 5 shows the comparison between $\mathrm{BC}$ vertical profiles during all HIPPO campaigns with CAM5 simulations for five latitude bins (90$60^{\circ} \mathrm{S}, 60-20^{\circ} \mathrm{S}, 20^{\circ} \mathrm{S}-20^{\circ} \mathrm{N}, 20-60^{\circ} \mathrm{N}$ and $60-90^{\circ} \mathrm{N}$ ), respectively. The modified CAM5 simulations agreed better with the observations in all regions, but they still overestimated $\mathrm{BC}$ in the middle and upper troposphere over the tropics, which may lead to a low bias in the model-simulated $\mathrm{BrC} / \mathrm{BC}$ heating ratio in the tropics (to be discussed in Sect. 5.3).

\subsection{Aerosol optical depth and absorption aerosol optical depth over fire-emission-dominated regions}

Direct assessments of $\mathrm{BrC}$ sources using observations are difficult because of limited observations. We can, however, evaluate model simulations of fire aerosols with aerosol optical depth (AOD) and absorption aerosol optical depth (AAOD) measurements. For this purpose, we chose the months and regions in model simulations for which $>50 \%$ of monthly mean AOD data are from fire emissions for 2010. The distribution of model-simulated mean AOD for data points selected in this manner are shown in Fig. S1a in the Supplement. For comparison purposes, the ground-based AOD measurements were obtained from the Aerosol Robotic Network (AERONET) version 3 level 2.0 dataset (Holben et al., 1998). To compare with model-simulated AOD data at $550 \mathrm{~nm}$, the AOD measurements at 500 and $675 \mathrm{~nm}$ were used to compute the Ångström exponent (Ångström, 1964) and calculate the corresponding AOD values at $550 \mathrm{~nm}(\mathrm{Ku}-$ mar et al., 2013). Figure 6a compares the monthly mean firedominated $550 \mathrm{~nm}$ AOD observations in 2010 in AERONET with corresponding monthly mean model results for selected months and regions. The correlation coefficient $r$ is high at 0.88 . We performed principal-component (PC) regression analysis of observed and simulated data. The low regression slope (0.56) indicates that the observed AOD data were underestimated, implying a low bias in fire emissions.

We also compared AOD with the measurements from the Moderate Resolution Imaging Spectroradiometer (MODIS) on Terra (EOS AM-1) satellite for the months and regions in model simulations for which $>50 \%$ of monthly mean AOD data are from fire emissions for 2010. We used collection 6 of the MODIS level 3 Deep Blue-Dark Target merged product with a resolution of $1^{\circ} \times 1^{\circ}$ (Platnick et al., 2017). Figure $6 \mathrm{~b}$ shows the comparison. Both the correlation coefficient $r(0.67)$ and the PC regression slope $k(0.49)$ are
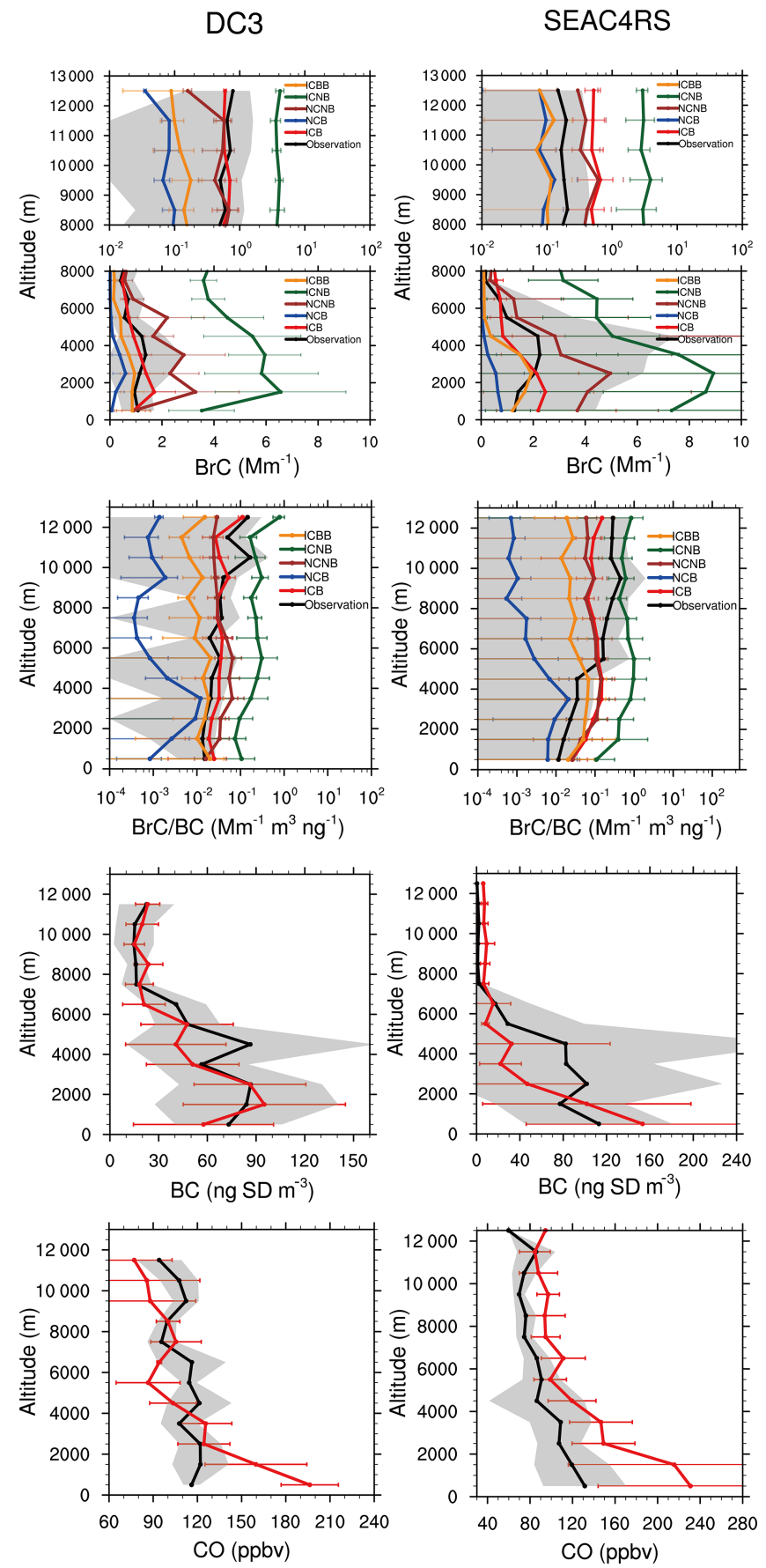

Figure 8. Comparison between observed and simulated vertical profiles of $\mathrm{BrC}$ absorption at $365 \mathrm{~nm}$, the ratio between $\mathrm{BrC}$ absorption at $365 \mathrm{~nm}$ and $\mathrm{BC}(\mathrm{BrC} / \mathrm{BC})$, and concentrations of $\mathrm{BC}$ and $\mathrm{CO}$ for the DC3 (left column) and SEAC4RS (right column) missions. Black lines and shaded areas show the means and standard deviations of the observations binned in $1 \mathrm{~km}$ intervals, respectively. The colored vertical lines and horizontal bars show the means and standard deviations of corresponding model results, respectively. Model sensitivity simulations of $\mathrm{BrC}$ are listed in Table 2 . The difference among simulated $\mathrm{BC}$ and $\mathrm{CO}$ vertical profiles is negligible, and the ICB simulation results are shown. 
Table 2. BrC sensitivity simulations.

\begin{tabular}{lrrrrr}
\hline CAM run name & $\begin{array}{r}\text { NCNB } \\
\text { (base model) }\end{array}$ & ICNB & NCB & ICBB & $\begin{array}{r}\text { ICB } \\
\text { (best model) }\end{array}$ \\
\hline Reduced BrC convective wet scavenging & No & Yes & No & Yes & Yes \\
Photobleaching of convective transported BrC & No & No & Yes & Yes & No \\
Photobleaching of non-convective transported BrC & No & No & Yes & Yes & Yes \\
\hline
\end{tabular}

lower than the comparison with AERONET observations. One reason is that the high AOD data in the outflow region of the tropical Atlantic from fire emissions over Africa were significantly underestimated (Fig. S1b); similar low biases were also found in the outflow region of fire emissions in South America. Additionally, CAM5 underestimates AOD at high latitudes (Liu et al., 2012). The general low bias of fire aerosol emissions was also found by Ward et al. (2012). For these data, the effect of $\mathrm{BrC}$ absorption on AOD is small; we estimate that $\mathrm{BrC}$ absorption contributes $0.37 \%$ of the total AOD.

In addition, we compared the model simulations to the AAOD data from the AERONET version 3 level 2.0 inversion dataset (Holben et al., 2006). Since the AAOD estimation is highly uncertain in the low AOD conditions (Dubovik et al., 2000), we used only AAOD measurements for AOD at $440 \mathrm{~nm} \geq 0.4$ (Holben et al., 2006). Monthly mean AAOD data were computed for AERONET sites with more than $10 \mathrm{~d}$ of daily averaged observed AOD at $440 \mathrm{~nm}>0.4$ in a month. Because of the model underestimation, the corresponding model threshold of AOD at $440 \mathrm{~nm}$ is 0.315 based on the PC regression between AERONET observations and model simulation results (Fig. 6a). Daily model results with AOD at $440 \mathrm{~nm}>0.315$ were used to compute simulated monthly means for the grid cells corresponding to the AERONET sites. To show the performance of the model simulation of aerosol absorption, here we compare the observed and simulated AAOD values at $550 \mathrm{~nm}$, which is near the peak wavelength of solar intensity. Because of the strong wavelength dependence of $\mathrm{BrC}$ absorption, the enhancement of AAOD by BrC absorption at wavelengths lower than $550 \mathrm{~nm}$ is more significant. Figure 6c compares the monthly mean 2005-2014 AERONET AAOD data over fire-dominated regions and months with the corresponding monthly mean model results. The observations showed significant interannual variability, which was not included in the model results for the climatological year 2010. With BrC absorption, the simulated higher AAOD data are in better agreement with AERONET observations with a PC regression slope of 0.59 compared to a slope of 0.43 for the simulation without $\mathrm{BrC}$ absorption. For these observations, the model underestimated the AERONET AAOD observations by $39 \%$ without $\mathrm{BrC}$ absorption. Including $\mathrm{BrC}$ absorption reduced the low bias to $17 \%$, which is well within the large variability of the observations. Globally, the AAOD absorption at $550 \mathrm{~nm}$ is higher by $8.5 \%$ on average when $\mathrm{BrC}$ is considered in the model simulations.

\section{Results}

\subsection{Model simulations of BrC for the DC3 and SEAC4RS missions}

We evaluated $\mathrm{BrC}$ model simulations using the measured $\mathrm{BrC}$ absorption data from the airborne measurements of Studies of Emissions, Atmospheric Composition, Clouds and Climate Coupling by Regional Surveys (Toon et al., 2016) and Deep Convective Clouds and Chemistry Project field experiments (Barth et al., 2015). The SEAC4RS campaign was conducted from 6 August to 23 September 2013 over the central and southeast US, and the DC3 campaign was conducted from 18 May to 22 June 2012 over a similar region. Flight tracks for these experiments are shown in Fig. 7. Fresh fire plume data, diagnosed by plumes with a coefficient of determination between $\mathrm{CO}$ and $\mathrm{CH}_{3} \mathrm{CN}>0.5$ during the period of enhanced $\mathrm{CO}$, were not included in the model evaluation as in previous studies (De Gouw et al., 2004; Liu et al., 2014).

We described in Sect. 3.1 the rationale for sensitivity simulations to evaluate the effects of $\mathrm{BrC}$ photobleaching and convective wet scavenging. The model sensitivity simulations are listed in Table 2. In the NCNB (base) model, neither effect was included. In the NCB model, the photobleaching effect is included. In the ICNB model, the wet scavenging efficiency of convective transported $\mathrm{BrC}$ was decreased from $75 \%$ simulated in the base model to $30 \%$ such that $\sim 70 \%$ of $\mathrm{BrC}$ was transported through convection to the free troposphere as suggested by Zhang et al. (2017). In the ICB model, both photobleaching and reduced convective scavenging effects were included. The ICBB model is similar to ICB model, but photobleaching of all $\mathrm{BrC}$ was included; in the other models including the photobleaching effect only non-convectively transported $\mathrm{BrC}$ was affected (Zhang et al., 2017).

Figure 8 shows the observed vertical profiles of $\mathrm{BrC}$ absorption, the $\mathrm{BrC}$-to- $\mathrm{BC}$ absorption ratio ( $\mathrm{BrC} / \mathrm{BC}$ ratio), and concentrations of $\mathrm{BC}$ and $\mathrm{CO}$ during the $\mathrm{DC} 3$ and SEAC4RS experiments in comparison to the corresponding model simulation results. The difference between $\mathrm{BC}$ and $\mathrm{CO}$ vertical profiles is negligible among the sensitivity simulations. Simulated mean BC concentrations are within the 

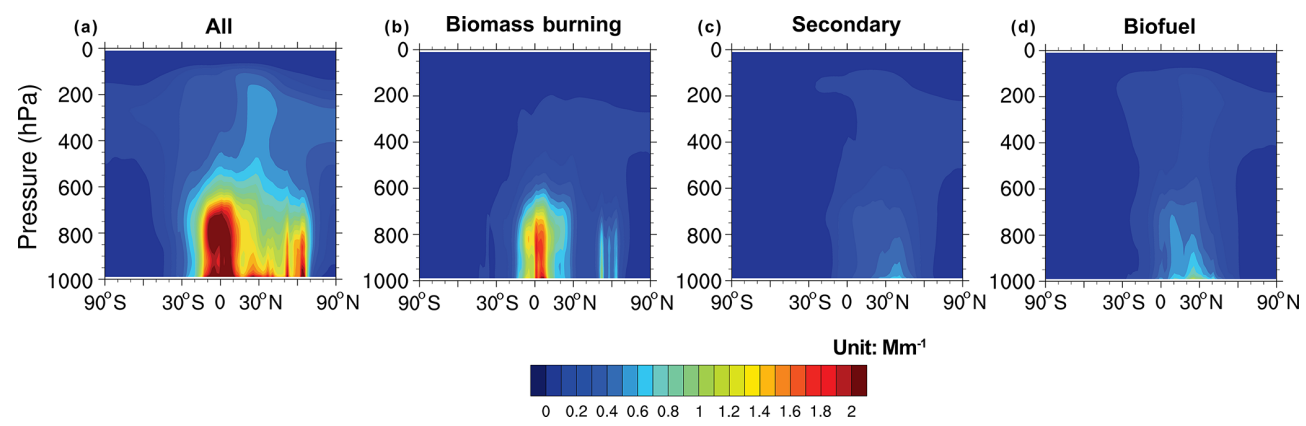

Figure 9. Simulated zonal averaged annual mean $\mathrm{BrC}$ absorption at $365 \mathrm{~nm}\left(\mathrm{Mm}^{-1}\right)$ for (a) all sources, (b) biomass burning emissions, (c) secondary $\mathrm{BrC}$ formation and (d) biofuel $\mathrm{BrC}$ emissions. The unit is $\mathrm{Mm}^{-1}$. The colored bar is in log scale.

uncertainties of the measurements. The underestimation at 2-5 km during SEAC4RS likely reflects underestimated fire emissions since the coefficient of determination $\left(R^{2}\right)$ is 0.6 for $\mathrm{HCN}$ and $\mathrm{BC}$ at $2-5 \mathrm{~km}$ and 0.5 for $\mathrm{HCN}$ and $\mathrm{BrC}$, reflecting the effects of biomass burning emissions on $\mathrm{BC}$ and $\mathrm{BrC}$. The higher $\mathrm{CO}$ concentrations in the model than the observations, particularly near the surface, suggest that the model overestimates surface $\mathrm{CO}$ emissions.

Table 2 lists all sensitivity simulations. For $\mathrm{BrC}$ and $\mathrm{BrC} / \mathrm{BC}$ simulations, Fig. 8 shows that the NCNB model clearly overestimated $\mathrm{BrC}$ compared to the observations at $0-8 \mathrm{~km}$ (the overestimate is not as apparent in the $\mathrm{BrC} / \mathrm{BC}$ comparison because it is a logarithmic scale). The overestimation reflected the importance of photobleaching (Forrister et al., 2015; Sareen et al., 2013; Lee et al., 2014; Wang et al., 2016; Wong et al., 2017, 2019; Zhong and Jang, 2011). The overestimation in the lower troposphere in NCNB led to a reasonable simulation of $\mathrm{BrC}$ in the upper troposphere, although the underestimation at $12 \mathrm{~km}$ was obviously relative to the ICB simulation during the DC3 experiment. Similarly, considering enhanced convective transport, but not photobleaching, the ICNB simulation clearly overestimated $\mathrm{BrC}$ absorption relative to the observations. Including photobleaching, but not enhanced convective transport of $\mathrm{BrC}$, the $\mathrm{NCB}$ simulation clearly underestimated $\mathrm{BrC}$ and the $\mathrm{BrC} / \mathrm{BC}$ ratio in comparison to the observations. We also included a simulation of ICBB, in which enhanced convective transport of $\mathrm{BrC}$ was included with photobleaching. Compared to the observations, upper-tropospheric $\mathrm{BrC}$ and the $\mathrm{BrC} / \mathrm{BC}$ ratio in the ICBB simulation were clearly underestimated. At $12 \mathrm{~km}$, the observed $\mathrm{BrC} / \mathrm{BC}$ ratio is $\sim 10$ and $\sim 20$ times higher than $\mathrm{BrC} / \mathrm{BC}$ near the surface during $\mathrm{DC}$ 3 and SEAC4RS, respectively. This increase in the $\mathrm{BrC} / \mathrm{BC}$ ratio in the upper troposphere was captured by the ICB simulation. On the basis of our current understanding of $\mathrm{BrC}$ processes (Forrister et al., 2015; Sareen et al., 2013; Lee et al., 2014; Wang et al., 2016; Wong et al., 2017, 2019; Zhang et al., 2017; Zhong and Jang, 2011) and the model evaluation with the observations, we chose the ICB simulation to investigate the effects of global $\mathrm{BrC}$ radiative forcing.
During the SEAC4RS experiment, Fig. 8 shows that the models overestimated both $\mathrm{BC}$ and $\mathrm{BrC}$ in the upper troposphere (except ICBB and $\mathrm{NCB}$, which underestimated $\mathrm{BrC}$ in both experiments), that all model simulations except ICNB underestimated the $\mathrm{BrC} / \mathrm{BC}$ ratio in the upper troposphere, and that all model simulations except NCB were overestimated the $\mathrm{BrC} / \mathrm{BC}$ ratio in the middle and lower troposphere. The simulation bias is mostly due to biases in the $\mathrm{BC}$ simulation in that $\mathrm{BC}$ was overestimated in the upper troposphere and underestimated in the middle and lower troposphere (Fig. 8).

In the ICB simulation, wet scavenging of $\mathrm{BrC}$ was reduced relative to $\mathrm{BC}$ in order to simulate the observed $\mathrm{BrC} / \mathrm{BC}$ ratios in DC3 and SEAC4RS. The mechanisms are not yet clear due to a lack of laboratory and field observations. Hydrophobic OC, such as humic-like substances (HULISs), is more likely to have high light absorption compared to hydrophilic OC (Hoffer et al., 2006). BrC with a high molecular weight dominates the aged biomass burning plume (Wong et al., 2017, 2019). Since higher molecular weight compounds have lower hygroscopicity (Dinar et al., 2007) and it is harder to activate hydrophobic OC in clouds, less $\mathrm{BrC}$ is removed in deep convection. Another possible mechanism is production of $\mathrm{BrC}$ through in-cloud heterogeneous processing of fire plumes (Zhang et al., 2017). However, there is no observation data to implement such a mechanism in a model.

\subsection{Simulated global zonal mean distribution of $\mathrm{BrC}$}

We performed diagnostic model simulations to investigate the contributions of $\mathrm{BrC}$ absorption from biomass burning emissions, biofuel emissions and secondary formation, respectively. Figure 9 shows the results. Secondary BrC production has a relatively small contribution because the photobleaching of secondary $\mathrm{BrC}$ is $100 \%$, while a small fraction of $\mathrm{BrC}$ is left after photobleaching of biomass burning and biofuel BrC (Forrister et al., 2015). Both biofuel and secondary production are largest at northern mid latitudes since they are due to anthropogenic emissions.

Biomass burning $\mathrm{BrC}$ shows drastically different distributions from biofuel $\mathrm{BrC}$. The latitudinal maximum is in the 

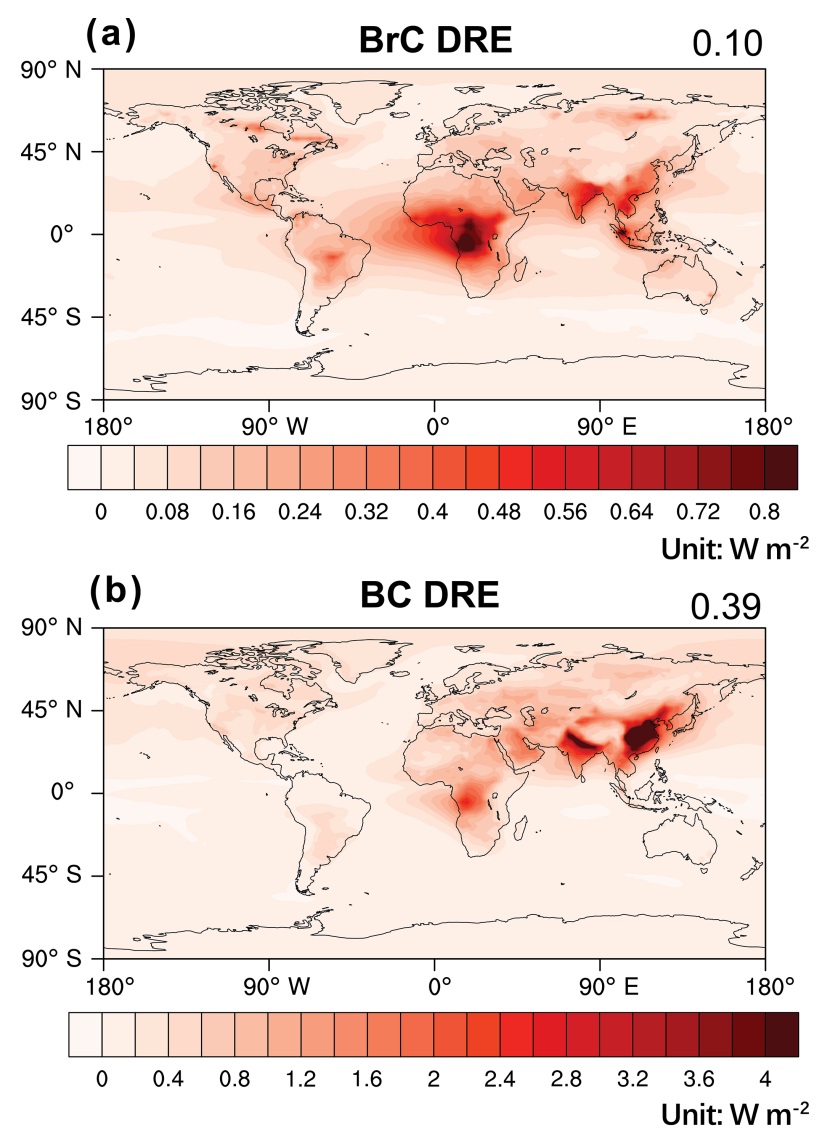

(c) BrC/BC DRE ratio

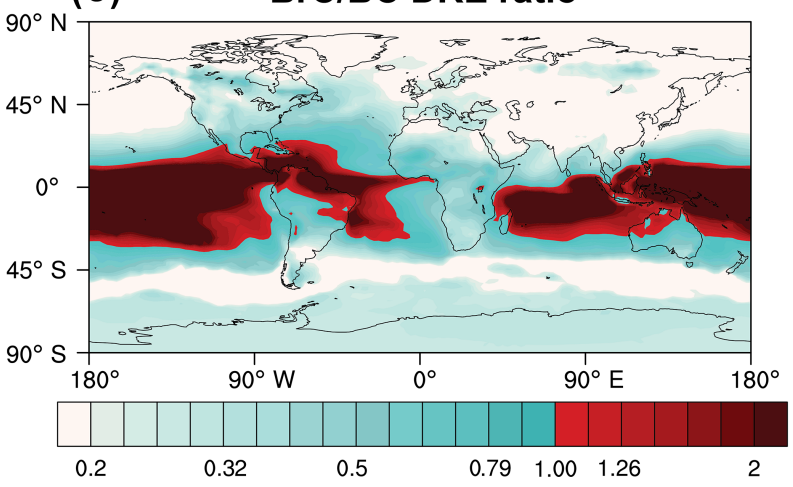

Figure 10. Annual averaged global distributions of (a) BC DRE, (b) BrC DRE and (c) the ratio of BrC/BC DRE for 2010. The unit is $\mathrm{W} \mathrm{m}^{-2}$. The global averaged DRE is shown in the upper right corner. In (c), BrC/BC DRE ratios larger than 1.0 are specified by a differently colored bar.

tropics and subtropics, with a secondary peak at $60^{\circ} \mathrm{N}$ due to fires over Canada and Siberia. The vertical extent of biomass burning $\mathrm{BrC}$ is much higher than biofuel $\mathrm{BrC}$ due to fire plume rise (Ke, 2020) and the higher vertical extent of tropical convection than at mid latitudes. While the effect of biofuel $\mathrm{BrC}$ is primarily in the lower troposphere, the radiative forcing of biomass burning $\mathrm{BrC}$ is much more substantial in the free troposphere and therefore more strongly affects the atmosphere since solar heating of the atmosphere is generally weak.

\subsection{Global directive radiative effect of $\mathrm{BrC}$}

Aerosol DRE represents the instantaneous radiative effect of aerosols, which is sometimes confused with DRF (Heald et al., 2014; Ghan, 2013). We applied the Rapid Radiative Transfer Method for GCMs to $\mathrm{BrC}$ and $\mathrm{BC}$ radiative forcing. We parameterized the imaginary part of the $\mathrm{BrC}$ refractive index as an external input of RRTMG. As discussed in Sect. 3.2, the imaginary refractive index is specified at 0.045 at $550 \mathrm{~nm}$ and 0.043 at $365 \mathrm{~nm}$ for primary and secondary BrC, respectively. The RRTMG shortwave and longwave wavelength boundaries are listed in Tables S1a and S1b in the Supplement (Neale et al., 2010; Iacono et al., 2008; Mlawer et al., 1997). We calculated the imaginary refractive index at a different wavelength by introducing wavelength dependence $w$ (Saleh et al., 2014).

$w=\mathrm{AAE}-1$,

$k_{\mathrm{BrC}, \lambda}=k_{\mathrm{BrC}, 550} \times\left(\frac{550}{\lambda}\right)^{w}$,

where $k_{\mathrm{BrC}, \lambda}$ denotes the imaginary refractive index of $\mathrm{BrC}$ and $w$ is the wavelength-dependent AAE value. The calculation and parameterization of MAE and the imaginary refraction index of $\mathrm{BrC}$ were discussed in Sect. 3.1.

In our estimation of BrC DRE, we only considered the absorption of $\mathrm{BrC}$, and the effect of scattering is not considered. We computed the clear-sky net solar flux at the top of atmosphere in two simulations, one with BrC-tracer-absorbing light and the other without. The difference between the two simulations is BrC DRE. The same method was used to calculate BC DRE.

The ICB model calculated global DRE distributions of $\mathrm{BrC}, \mathrm{BC}$, and the DRE ratio of $\mathrm{BrC}$ to $\mathrm{BC}$; the DRE distributions are shown in Fig. 10. For 2010, we estimated the global averaged DRE of $\mathrm{BrC}$ absorption at $0.10 \mathrm{~W} \mathrm{~m}^{-2}$ in comparison to $0.39 \mathrm{~W} \mathrm{~m}^{-2}$ by BC. While the global DRE by BrC is less than $\mathrm{BC}$, regional $\mathrm{BrC}$ DRE can be as large as that of $\mathrm{BC}$ due to the large difference in emission distributions. BC DRE is large at northern mid latitudes due to anthropogenic emissions from China and India. $\mathrm{BrC}$ emissions are relatively low in these regions (Fig. 1), and consequently BC DRE dominates. Over regions with large fire emissions, both $\mathrm{BC}$ and $\mathrm{BrC}$ are important. Over most regions of the remote tropical ocean, BrC DRE is larger than BC, despite a model high bias of simulated $\mathrm{BC}$ in the middle and upper tropical troposphere (Fig. 5), suggesting significant broad regional effects by $\mathrm{BrC}$ radiative forcing in the tropics. This simulated feature is due to two factors. In the ICB simulation, wet scavenging removes much more $\mathrm{BC}$ than $\mathrm{BrC}$. Therefore, $\mathrm{BrC}$ is enriched relative to $\mathrm{BC}$ in the free troposphere (e.g., Zhang et al., 2017). In the tropics, the easterly trade winds in the boundary layer become westerlies in the middle and upper 

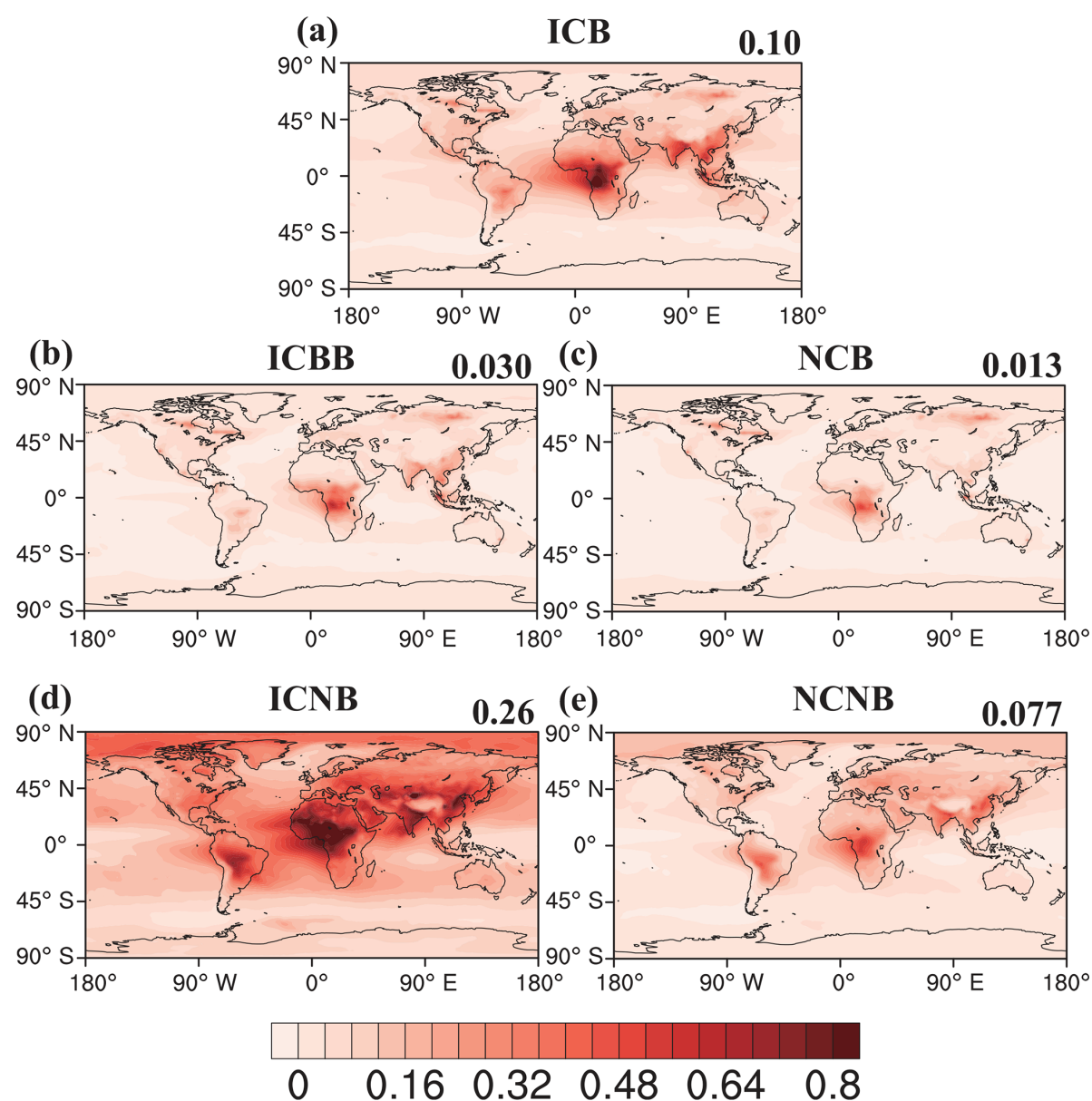

Figure 11. Annual averaged global distributions of BrC DRE for all sensitivity simulations (Table 2). The unit is $\mathrm{W} \mathrm{m}{ }^{-2}$. The global averaged DRE is shown in the upper right corner.

troposphere. The regions of boundary layer BC transport and free-tropospheric $\mathrm{BrC}$ transport are in opposite directions. As a result, the DRE ratio of $\mathrm{BrC}$ to $\mathrm{BC}$ is low to the east of the fire emission regions, and it is high to the west of the fire emission regions.

To discuss our simulation results in the context of previous modeling studies, which did not use the ICB assumptions, we show the annual mean DRE distributions for all model simulations (Table 2) in Fig. 11. Comparing the global mean DRE relative change of ICB $\left(0.10 \mathrm{~W} \mathrm{~m}^{-2}\right)$ to $\mathrm{NCB}\left(0.013 \mathrm{~W} \mathrm{~m}^{-2}\right)$ with that of NCNB $\left(0.077 \mathrm{~W} \mathrm{~m}^{-2}\right)$ to NCB shows that the global effect of a convective scavenging efficiency decrease is larger than photobleaching. A similar conclusion can be obtained by comparing the global mean DRE relative change of ICNB $\left(0.26 \mathrm{~W} \mathrm{~m}^{-2}\right)$ to NCNB with that of ICNB to ICB. The DRE relative change from ICB to ICBB $\left(0.030 \mathrm{~W} \mathrm{~m}^{-2}\right)$ indicates that the photobleaching effect of convectively transported $\mathrm{BrC}$ is larger than the enhancement of $\mathrm{BrC}$ convective transport. The $0.013 \mathrm{~W} \mathrm{~m}^{-2} \mathrm{DRE}$ in the NCB simulation is lower than previous model studies considering the photobleaching effect (Wang et al., 2018; Brown et al., 2018). In the NCB simulation, remote $\mathrm{BrC}$ concentrations are mostly affected by the threshold for photobleaching, which is $6 \%$ in this study (Forrister et al. 2015) in comparison to $25 \%$ in Wang et al. (2018) and Brown et al. (2018), causing the difference in the global DRE estimates with photobleaching between this work and previous studies. The $0.077 \mathrm{~W} \mathrm{~m}^{-2}$ DRE in the NCNB simulation is comparable to previous studies (Feng et al., 2013; Jo et al., 2016; Wang et al., 2014).

Only ICB simulation results are discussed hereafter. Figure 12 shows the seasonally BrC DRE distributions. The seasonal variation is due primarily to biomass burning. Figure 2 shows that the largest fire emissions in August, September, July and June. While fire emissions are mostly in the tropics in SON, burning at northern mid and high latitudes is much more pronounced in June-July-August (JJA) in addition to tropical burning.

\subsection{Global effects of $\mathrm{BrC}$ absorption on the atmosphere}

As found by Zhang et al. (2017), the importance of radiative heating by $\mathrm{BrC}$ relative to $\mathrm{BC}$ increases with altitude due 

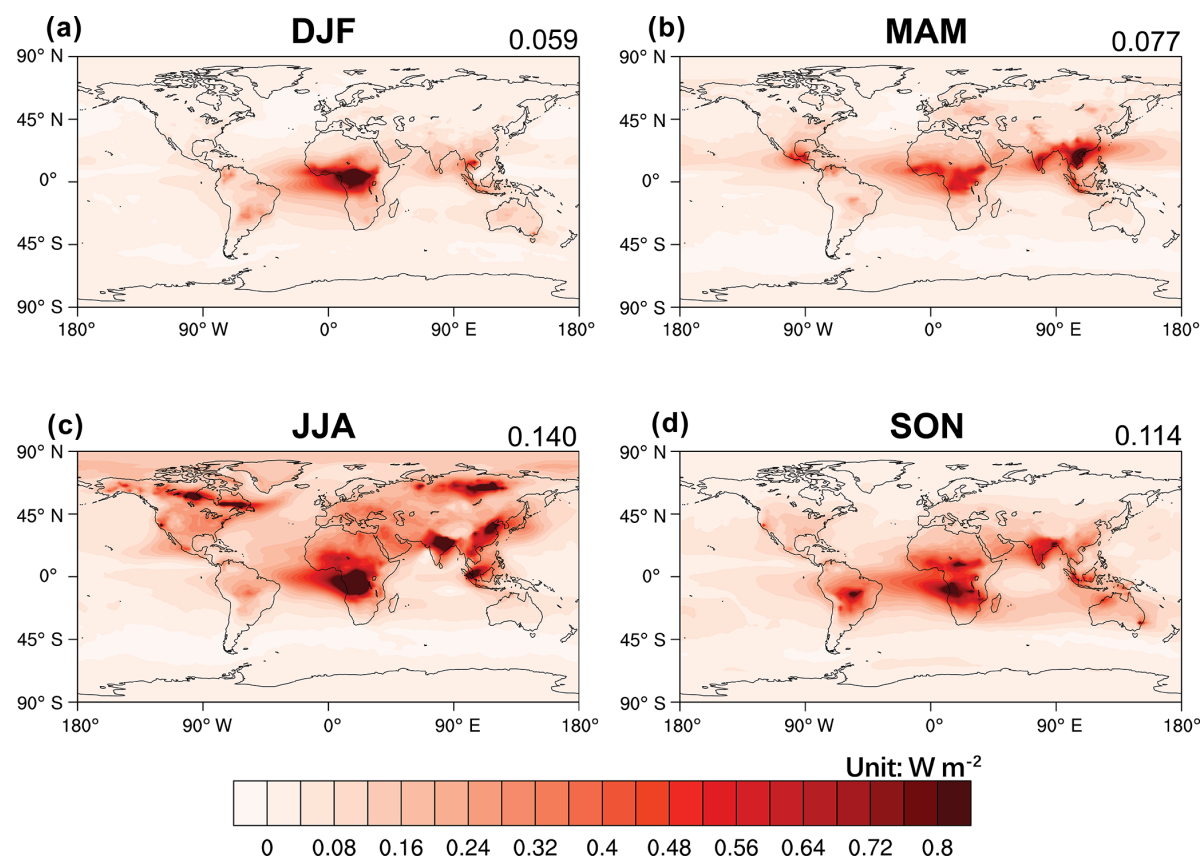

Figure 12. Same as Fig. 10 but for seasonal global DRE distributions of BrC for (a) December-January-February (DJF), (b) March-AprilMay (MAM), (c) June-July-August (JJA) and (d) September-October-November (SON) in the ICB simulation.
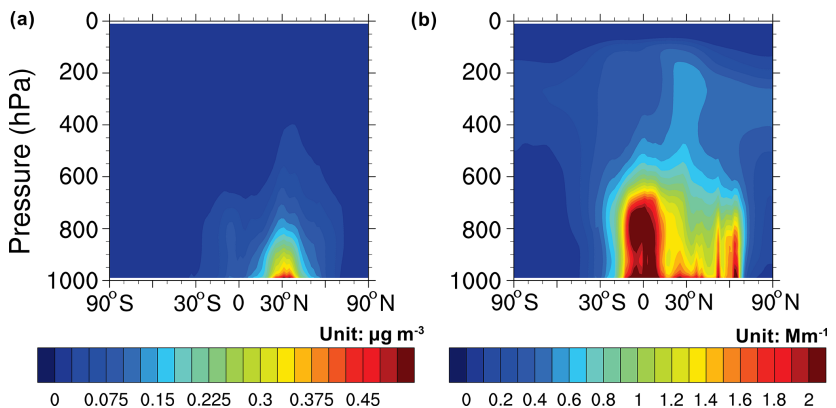

Figure 13. Global zonal mean distributions of (a) BC mass concentrations ( $\mu \mathrm{g} \mathrm{std} \mathrm{m}^{-3}$; mass concentration under standard conditions) and (b) BrC absorption at $365 \mathrm{~nm}\left(\mathrm{Mm}^{-1}\right)$ for 2010 .

to convective transport. We compared the difference of average vertical profiles of the $\mathrm{BrC}$-to-BC heating rate ratio in Fig. 14. Over regions directly affected by convection, where the convective mass flux is $>10^{-5} \mathrm{~kg} \mathrm{~m}^{-2} \mathrm{~s}^{-1}$, the simulated result is in agreement with Zhang et al. (2017). Globally, the average $\mathrm{BrC} / \mathrm{BC}$ heating rate ratio is $15 \%$ below $500 \mathrm{hPa}$ and $44 \%$ above $500 \mathrm{hPa}$. In deep-convection regions, the average $\mathrm{BrC} / \mathrm{BC}$ heating rate ratio is $60 \%$ below $500 \mathrm{hPa}$ and $118 \%$ above $500 \mathrm{hPa}$, indicating that in deep-convection regions, atmospheric heating of $\mathrm{BrC}$ is stronger than that of $\mathrm{BC}$. In comparison, over the regions not directly affected by deep convection, the globally averaged $\mathrm{BrC} / \mathrm{BC}$ heating rate ratio increases from $9 \%$ at surface level to $53 \%$ in the upper troposphere. Geographically, Fig. 15 shows that the dif-

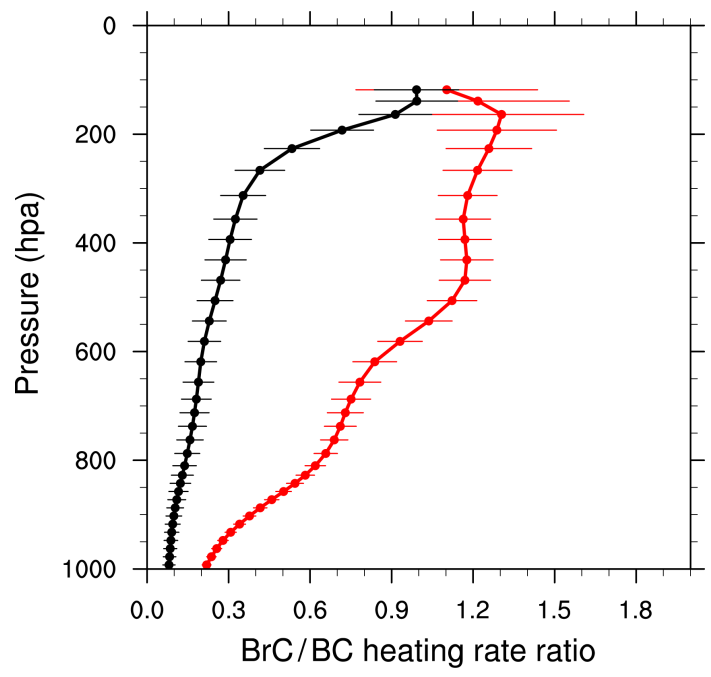

Figure 14. Global averaged vertical profile of the BrC-to-BC heating rate ratio for 2010 . The black and red lines are the average profiles for regions without and with deep-convection events, respectively. Standard deviations are indicated by the horizontal bars.

ference between $\mathrm{BrC}$ and $\mathrm{BC}$ is particularly large over the tropics.

The heating rate from aerosols, especially its vertical profile, has significant implications on cloud dynamics (e.g., Bond et al., 2013) and can also induce feedback from regional circulation and the planetary boundary layer dynamics (e.g., Ramanathan and Carmichael, 2008). We conducted 


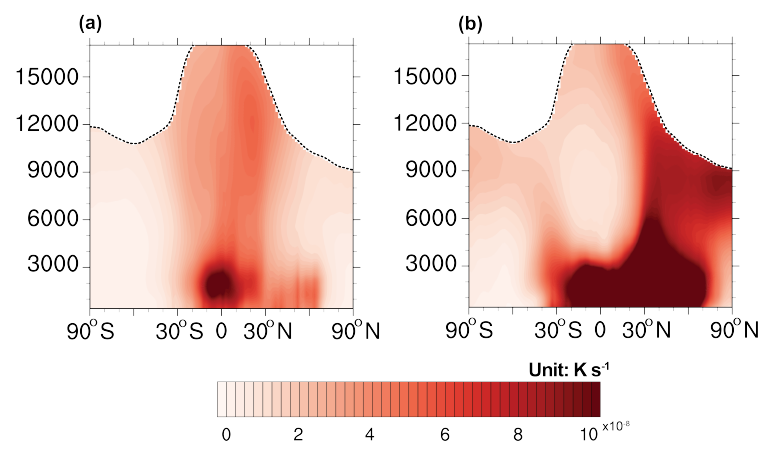

Figure 15. Global zonal mean distributions of the heating rate of (a) $\mathrm{BrC}$ and (b) $\mathrm{BC}$ for 5 years of present-day simulations. The dashed line denotes the tropopause.

three 5-year free-running model simulations for the present day (the year 2010). In the control simulation, both $\mathrm{BrC}$ and $\mathrm{BC}$ heat were included. We then conducted sensitivity simulations in which only $\mathrm{BrC}$ or $\mathrm{BC}$ heating was included. By comparing the sensitivity simulation results to the control simulation, we diagnosed the climate response to differential $\mathrm{BrC}$ and $\mathrm{BC}$ heating.

The latitudinal and vertical difference between $\mathrm{BrC}$ and $\mathrm{BC}$ heating (Figs. 14 and 15) implies that $\mathrm{BrC}$ heating is more dominant in the tropics and tends to decrease the vertical gradient of temperature. Allen et al. (2012) suggested that light-absorbing aerosols may contribute to tropical expansion. They did not consider the effect of $\mathrm{BrC}$, the atmospheric heating effect of which is more concentrated in the tropics than BC heating (Fig. 15). Using the latitude where the mean meridional circulation (MMC) at $500 \mathrm{hPa}$ becomes zero on the poleward side of the subtropical maximum to diagnose the boundary of the tropics (Zhou et al., 2011), we estimated a $1.0 \pm 0.9^{\circ}$ latitude of tropical expansion due to $\mathrm{BrC}$ heating in comparison to a $1.2 \pm 2.9^{\circ}$ expansion due to $\mathrm{BC}$ heating. The large uncertainty comes from 5 years of free-running simulations and the relatively low model spatial resolution. Another effect from $\mathrm{BrC}$ heating is the decrease of deep-convective mass flux over the upper troposphere (Feingold et al., 2005; Yoshimori and Broccoli, 2008). We estimated a decrease of deep-convective mass flux by $4.41 \times 10^{-5} \mathrm{~kg} \mathrm{~m}^{-2} \mathrm{~s}^{-1}$ or $4.1 \%$ over the tropics, which is about one third of the corresponding $\mathrm{BC}$ heating effect $\left(1.52 \times 10^{-4} \mathrm{~kg} \mathrm{~m}^{-2} \mathrm{~s}^{-1}\right.$ or $\left.12.9 \%\right)$.

Hodnebrog et al. (2016) suggested that biomass burning aerosols suppress precipitation regionally due primarily to aerosol-cloud interactions. On a global basis, $\mathrm{BrC}$ heating reduces precipitation by $0.9 \% \pm 7.0 \%$, which is about $60 \%$ of the precipitation reduction by $\mathrm{BC}$ simulated in the model. Over the tropical region with high-intensity convection and precipitation, $\mathrm{BrC}$ heating decreased precipitation by $3.9 \% \pm$ $17.8 \%$, similar to that from $\mathrm{BC}$ heating $(4.0 \% \pm 17.1 \%)$. The effect of $\mathrm{BrC}$ heating on tropical precipitation $(\sim 100 \%)$ is larger than on convective mass flux (about one third) relative to $\mathrm{BC}$ heating because of the stronger $\mathrm{BrC}$ than $\mathrm{BC}$ heating in the upper than lower troposphere (Figs. 14 and 15). BrC heating decreased precipitation by $0.3 \% \pm 10.7 \%$ in the northern mid and high latitudes, which is much lower than the effect of $\mathrm{BC}$ heating $(-4.8 \% \pm 13.5 \%)$.

\section{Conclusions}

Light-absorbing aerosols, including $\mathrm{BC}$ and $\mathrm{BrC}$, have significant impacts on the global radiative balance. Observational evidence emerged from the DC3 mission of large enhancements of $\mathrm{BrC}$ relative to $\mathrm{BC}$ over biomass burning regions (Zhang et al., 2017). We developed a module for simulating the effects of brown carbon light absorption in CAM5 of CESM and conducted two sets of model experiments, 2010 with nudged meteorological fields and 5year free-running simulations. Compared to previous studies which did not consider differential convective transport of $\mathrm{BrC}$ and $\mathrm{BC}$, the simulated $\mathrm{BrC}$ DREs without (NCNB) and with $(\mathrm{NCB})$ photobleaching are comparable to previous studies (Feng et al., 2013; Jo et al., 2016; Wang et al., 2018; Brown et al., 2018). However, evaluations with DC3, SEAC4RS and HIPPO observations suggested that the model could simulate the observed concentrations of $\mathrm{BrC}$ and $\mathrm{BC}$, although model biases were also found. Reducing the convective scavenging efficiency and including photobleaching were necessary to simulate the observed $\mathrm{BrC}$ distributions. Globally, the former effect is larger than the latter on simulated $\mathrm{BrC}$ absorption. Since the two factors have opposite effects on simulated $\mathrm{BrC}$ DRE, our best estimation of global DRE of $\mathrm{BrC}$ is $0.10 \mathrm{~W} \mathrm{~m}^{-2}$.

The BrC DRE is estimated to be $25 \%$ of that of BC. Since biomass burning emissions tend to occur during the warm seasons when solar insolation is strong and these emissions tend to occur in the tropics when convective transport is active, the proportional contribution to $\mathrm{BrC}$ DRE by biomass burning emission is larger than its fraction in the total emissions. For example, biofuel $\mathrm{BrC}$ emissions are seasonal and occur in mid and high latitudes, and the combination of $\mathrm{BrC}$ absorption and solar radiation of biofuel $\mathrm{BrC}$ is less than biomass burning $\mathrm{BrC}$ for a unit of $\mathrm{BrC}$ emission. Relative to BC DRE, BrC DRE tends to be larger in the tropics due to different emission distributions and larger $\mathrm{BrC}$ levels in the upper troposphere. $\mathrm{BrC}$ heating reduces global precipitation by $0.9 \%$, about $60 \%$ of the BC induced precipitation decrease. Over the tropics, the reduction of precipitation due to $\mathrm{BrC}$ heating is similar to $\mathrm{BC}$ heating, but its effect on reducing tropical convective mass flux is only about one third of $\mathrm{BC}$ heating because $\mathrm{BrC}$ heating is strongly skewed to high altitudes compared to $\mathrm{BC}$ heating. Consequently, the effect of $\mathrm{BrC}$ heating on tropical expansion is comparable to $\mathrm{BC}$ heating. 
There are still considerable uncertainties in modeling BrC absorption and its effects in the atmosphere. The parameterizations of emissions, photobleaching and convective transport of $\mathrm{BrC}$ all require more field and laboratory observations. The uncertainty of model-simulated $\mathrm{BC}$ also affects the comparison between the DRE and heating of $\mathrm{BC}$ and BrC. For example, the model overestimates of $\mathrm{BC}$ in the middle and upper tropical troposphere (Fig. 5) may lead to an underestimate of the BrC-to-BC DRE ratio over the remote tropics. The modeling results of stronger atmospheric heating by $\mathrm{BrC}$ than $\mathrm{BC}$ over the tropical free troposphere in this study are also subject to these uncertainties. Field measurements over tropical convective regions during periods of biomass burning are critically needed to further improve our understanding of $\mathrm{BrC}$ processes and its climate effects. Continuous model development by coupling BrC-related processes and climate effects into an interactive climate-fireecosystem model (Zou et al., 2019) in CESM would also benefit future projections of climate radiative forcing given large impacts of fire-emitted $\mathrm{BrC}$ in the tropics found by this study.

Data availability. NASA DC3 and SEAC4RS mission information and data are available to the general public through the NASA data archive (https://www-air.larc.nasa.gov/cgi-bin/ArcView/dc3; NASA, 2020a and https://www-air.larc.nasa.gov/cgi-bin/ArcView/ seac4rs, last access: 16 February 2020; NASA, 2020b). The MODIS Terra level 3 monthly dataset (MOD08_M3) is available via the NASA LAADS archive (https://ladsweb.modaps.eosdis.nasa.gov/ archive/allData/61/MOD08_M3/, last access: 24 December 2019; LAADS DAAC, 2019). HIPPO merged $10 \mathrm{~s}$ data are available via the CDIAC HIPPO data archive (https://hippo.ornl.gov/data_ access, last access: 8 September 2018; CDIAC HIPPO, 2018). AERONET AOD measurements are available at: https://aeronet. gsfc.nasa.gov/new_web/download_all_v3_aod.html (last access: 16 February 2020; NASA, 2020c). The CAM5 model results are available from the corresponding author upon request.

Supplement. The supplement related to this article is available online at: https://doi.org/10.5194/acp-20-1901-2020-supplement.

Author contributions. YZ and RJW provided the original idea. AZ, YW and YZ designed the model experiments. YS and ZK conducted and provided the model input data. RJW and YZ conducted and analyzed the aircraft measurement data. AZ carried out the model experiments and prepared the paper with contributions from all co-authors.

Competing interests. The authors declare that they have no conflict of interest.

Acknowledgements. This work was supported by the National Science Foundation (NSF) (grant no. 1243220). We would like to ac- knowledge high-performance computing support from Cheyenne (Computational and Information Systems Laboratory, 2017) and Yellowstone (ark:/85065/d7w3xhc) systems provided by the National Center for Atmospheric Research (NCAR) Computational \& Information Systems Lab (CISL), sponsored by the National Science Foundation. Rodney J. Weber was supported through the ATom project by the National Aeronautics and Space Administration (grant no. NNX15AT90G). We thank Haviland Forrister for helpful discussion.

Financial support. This research has been supported by the National Science Foundation (grant no. 1243220).

Review statement. This paper was edited by Qiang Zhang and reviewed by two anonymous referees.

\section{References}

Akagi, S. K., Yokelson, R. J., Wiedinmyer, C., Alvarado, M. J., Reid, J. S., Karl, T., Crounse, J. D., and Wennberg, P. O.: Emission factors for open and domestic biomass burning for use in atmospheric models, Atmos. Chem. Phys., 11, 4039-4072, https://doi.org/10.5194/acp-11-4039-2011, 2011.

Alexander, D. T., Crozier, P. A., and Anderson, J. R.: Brown carbon spheres in East Asian outflow and their optical properties, Science, 321, 833-836, https://doi.org/10.1126/science.1155296, 2008.

Allen, R. J., Sherwood, S. C., Norris, J. R., and Zender, C. S.: Recent Northern Hemisphere tropical expansion primarily driven by black carbon and tropospheric ozone, Nature, 485, 350-354, https://doi.org/10.1038/nature11097, 2012.

Ångström, A.: The parameters of atmospheric turbidity, Tellus, 16, 64-75, 1964.

Barth, M. C., Cantrell, C. A., Brune, W. H., Rutledge, S. A., Crawford, J. H., Huntrieser, H., Carey, L. D., MacGorman, D., Weisman, M., Pickering, K. E., and Bruning, E.: The deep convective clouds and chemistry (DC3) field campaign, B. Am. Meteorol. Soc., 96, 1281-1309, https://doi.org/10.1175/BAMS-D-13$00290.1,2015$.

Bond, T. C. and Bergstrom, R. W.: Light absorption by carbonaceous particles: An investigative review, Aerosol Sci. Technol., 40, 27-67, https://doi.org/10.1080/02786820500421521, 2006.

Bond, T. C., Bhardwaj, E., Dong, R., Jogani, R., Jung, S., Roden, C., Streets, D. G., and Trautmann, N. M.: Historical emissions of black and organic carbon aerosol from energy-related combustion, 1850-2000, Global Biogeochem. Cy., 21, GB2018, https://doi.org/10.1029/2006GB002840, 2007.

Bond, T. C., Doherty, S. J., Fahey, D., Forster, P., Berntsen, T., DeAngelo, B., Flanner, M., Ghan, S., Kärcher, B., and Koch, D.: Bounding the role of black carbon in the climate system: A scientific assessment, J. Geophys. Res.-Atmos., 118, 5380-5552, https://doi.org/10.1002/jgrd.50171, 2013.

Bretherton, C. S. and Park, S.: A new moist turbulence parameterization in the Community Atmosphere Model, J. Climate, 22, 3422-3448, https://doi.org/10.1175/2008JCLI2556.1, 2009. 
Brown, H., Liu, X., Feng, Y., Jiang, Y., Wu, M., Lu, Z., Wu, C., Murphy, S., and Pokhrel, R.: Radiative effect and climate impacts of brown carbon with the Community Atmosphere Model (CAM5), Atmos. Chem. Phys., 18, 17745-17768, https://doi.org/10.5194/acp-18-17745-2018, 2018.

Browne, E. C., Zhang, X., Franklin, J. P., Ridley, K. J., Kirchstetter, T. W., Wilson, K. R., Cappa, C. D., and Kroll, J. H.: Effect of heterogeneous oxidative aging on light absorption by biomassburning organic aerosol, Aerosol Sci. Technol., 53, 663-674, https://doi.org/10.1080/02786826.2019.1599321, 2019.

CDIAC HIPPO: data archive, available at: https://hippo.ornl.gov/ data_access, last access: 8 September 2018.

Chakrabarty, R. K., Moosmüller, H., Chen, L.-W. A., Lewis, K., Arnott, W. P., Mazzoleni, C., Dubey, M. K., Wold, C. E., Hao, W. M., and Kreidenweis, S. M.: Brown carbon in tar balls from smoldering biomass combustion, Atmos. Chem. Phys., 10, 63636370, https://doi.org/10.5194/acp-10-6363-2010, 2010.

Cheng, Y., He, K.-B., Zheng, M., Duan, F.-K., Du, Z.-Y., Ma, Y.-L., Tan, J.-H., Yang, F.-M., Liu, J.-M., Zhang, X.-L., Weber, R. J., Bergin, M. H., and Russell, A. G.: Mass absorption efficiency of elemental carbon and water-soluble organic carbon in Beijing, China, Atmos. Chem. Phys., 11, 11497-11510, https://doi.org/10.5194/acp-11-11497-2011, 2011.

Chipperfield, M.: New version of the TOMCAT/SLIMCAT offline chemical transport model: Intercomparison of stratospheric tracer experiments, Q. J. Roy. Meteorol. Soc., 132, 1179-1203, https://doi.org/10.1256/qj.05.51, 2006.

Computational and Information Systems Laboratory: Cheyenne: HPE/SGI ICE XA System (University Community Computing). Boulder, CO: National Center for Atmospheric Research, https://doi.org/10.5065/D6RX99HX, 2017

Costabile, F., Gilardoni, S., Barnaba, F., Di Ianni, A., Di Liberto, L., Dionisi, D., Manigrasso, M., Paglione, M., Poluzzi, V., Rinaldi, M., Facchini, M. C., and Gobbi, G. P.: Characteristics of brown carbon in the urban Po Valley atmosphere, Atmos. Chem. Phys., 17, 313-326, https://doi.org/10.5194/acp-17-313-2017, 2017.

De Gouw, J., Cooper, O., Warneke, C., Hudson, P., Fehsenfeld, F., Holloway, J., Hübler, G., Nicks Jr, D., Nowak, J., and Parrish, D.: Chemical composition of air masses transported from Asia to the US West Coast during ITCT 2K2: Fossil fuel combustion versus biomass-burning signatures, J. Geophys. Res.-Atmos., 109, D23S20, https://doi.org/10.1029/2003JD004202, 2004.

Desyaterik, Y., Sun, Y., Shen, X., Lee, T., Wang, X., Wang, T., and Collett, J. L.: Speciation of "brown" carbon in cloud water impacted by agricultural biomass burning in eastern China, J. Geophys. Res.-Atmos., 118, 7389-7399, https://doi.org/10.1002/jgrd.50561, 2013.

Di Lorenzo, R. A. and Young C. J.: Size separation method for absorption characterization in brown carbon: Application to an aged biomass burning sample, Geophys. Res. Lett., 43, 458-465, https://doi.org/10.1002/2015GL066954, 2015.

Di Lorenzo, R. A., Washenfelder R. A., Attwood, A. R., Guo, H., $\mathrm{Xu}, \mathrm{L} ., \mathrm{Ng}, \mathrm{S}$., Weber, R. J., Baumann, K., Edgerton, E., and Young, C. J.: Molecular-Size-Separated Brown Carbon Absorption for Biomass-Burning Aerosol at Multiple Field Sites, Environ. Sci. Technol, 51, 3128-3137, 2017.

Dinar, E., Taraniuk, I., Graber, E.R., Anttila, T., Mentel, T. F., and Rudich, Y.: Hygroscopic growth of atmospheric and model humic-like substances, J. Geophys. Res.-Atmos., 112, D05211, https://doi.org/10.1029/2006JD007442, 2007.

Dubovik, O., Smirnov, A., Holben, B. N., King, M. D., Kaufman, Y. J., Eck, T. F., and Slutsker, I.: Accuracy assessment of aerosol optical properties retrieval from AERONET sun and sky radiance measurements, J. Geophys. Res., 105, 9791-9806, https://doi.org/10.1029/2000JD900040, 2000.

Feingold, G., Jiang, H., and Harrington, J. Y.: On smoke suppression of clouds in Amazonia, Geophys. Res. Lett., 32, L02804, https://doi.org/10.1029/2004GL021369, 2005.

Feng, Y., Ramanathan, V., and Kotamarthi, V. R.: Brown carbon: a significant atmospheric absorber of solar radiation?, Atmos. Chem. Phys., 13, 8607-8621, https://doi.org/10.5194/acp13-8607-2013, 2013.

Fernandes, S. D., Trautmann, N. M., Streets, D. G., Roden, C. A., and Bond, T. C.: Global biofuel use, 1850-2000, Global Biogeochem. Cy., 21, GB2019, https://doi.org/10.1029/2006GB002836, 2007.

Forrister, H., Liu, J., Scheuer, E., Dibb, J., Ziemba, L., Thornhill, K. L., Anderson, B., Diskin, G., Perring, A. E., and Schwarz, J. P.: Evolution of brown carbon in wildfire plumes, Geophys. Res. Lett., 42, 4623-4630, https://doi.org/10.1002/2015GL063897, 2015.

Gettelman, A., Liu, X., Ghan, S. J., Morrison, H., Park, S., Conley, A., Klein, S. A., Boyle, J., Mitchell, D., and Li, J. L.: Global simulations of ice nucleation and ice supersaturation with an improved cloud scheme in the Community Atmosphere Model, J. Geophys. Res.-Atmos., 115, D18216, https://doi.org/10.1029/2009JD013797, 2010.

Ghan, S. J.: Technical Note: Estimating aerosol effects on cloud radiative forcing, Atmos. Chem. Phys., 13, 9971-9974, https://doi.org/10.5194/acp-13-9971-2013, 2013.

Ghan, S. J., Liu, X., Easter, R. C., Zaveri, R., Rasch, P. J., Yoon, J.H., and Eaton, B.: Toward a minimal representation of aerosols in climate models: Comparative decomposition of aerosol direct, semidirect, and indirect radiative forcing, J. Climate, 25, 64616476, https://doi.org/10.1175/JCLI-D-11-00650.1, 2012.

Giglio, L., Randerson, J. T., and Werf, G. R.: Analysis of daily, monthly, and annual burned area using the fourth-generation global fire emissions database (GFED4), J. Geophys. Res.Biogeosci., 118, 317-328, https://doi.org/10.1002/jgrg.20042, 2013.

Heald, C. L., Ridley, D. A., Kroll, J. H., Barrett, S. R. H., Cady-Pereira, K. E., Alvarado, M. J., and Holmes, C. D.: Contrasting the direct radiative effect and direct radiative forcing of aerosols, Atmos. Chem. Phys., 14, 5513-5527, https://doi.org/10.5194/acp-14-5513-2014, 2014.

Hecobian, A., Zhang, X., Zheng, M., Frank, N., Edgerton, E. S., and Weber, R. J.: Water-Soluble Organic Aerosol material and the light-absorption characteristics of aqueous extracts measured over the Southeastern United States, Atmos. Chem. Phys., 10, 5965-5977, https://doi.org/10.5194/acp-10-5965-2010, 2010.

Hodnebrog, Ø., Myhre, G., Forster, P. M., Sillmann, J., and Samset, B. H.: Local biomass burning is a dominant cause of the observed precipitation reduction in southern Africa, Nat. Commun., 7, https://doi.org/10.1038/ncomms11236, 2016.

Hoffer, A., Gelencsér, A., Guyon, P., Kiss, G., Schmid, O., Frank, G. P., Artaxo, P., and Andreae, M. O.: Optical properties of humiclike substances (HULIS) in biomass-burning aerosols, Atmos. 
Chem. Phys., 6, 3563-3570, https://doi.org/10.5194/acp-6-35632006, 2006.

Holben, B. N., Eck, T., Slutsker, I., Tanre, D., Buis, J., Setzer, A., Vermote, E., Reagan, J., Kaufman, Y., and Nakajima, T.: AERONET - A federated instrument network and data archive for aerosol characterization, Remote Sens. Environ., 66, 1-16, https://doi.org/10.1016/S0034-4257(98)00031-5, 1998.

Holben, B. N., Eck, T. F., Slutsker, I., Smirnov, A., Sinyuk, A.,Schafer, J., Giles, D., and Dubovik O.: AERONET's Version 2.0 quality assurance criteria, available at: http://aeronet.gsfc. nasa.gov/new_web/Documents/AERONETcriteria_final1.pdf (last access: 22 October 2019), 2006.

Iacono, M. J., Delamere, J. S., Mlawer, E. J., Shephard, M. W., Clough, S. A., and Collins, W. D.: Radiative forcing by long-lived greenhouse gases: Calculations with the AER radiative transfer models, J. Geophys. Res.-Atmos., 113, D13103, https://doi.org/10.1029/2008JD009944, 2008.

Jacobson, M. Z.: Isolating nitrated and aromatic aerosols and nitrated aromatic gases as sources of ultraviolet light absorption, J. Geophys. Res.-Atmos., 104, 3527-3542, https://doi.org/10.1029/1998JD100054, 1999.

Jacobson, M. Z.: Investigating cloud absorption effects: Global absorption properties of black carbon, tar balls, and soil dust in clouds and aerosols. J. Geophys. Res.-Atmos., 117, D06205, https://doi.org/10.1029/2011JD017218, 2016.

Jo, D. S., Park, R. J., Lee, S., Kim, S.-W., and Zhang, X.: A global simulation of brown carbon: implications for photochemistry and direct radiative effect, Atmos. Chem. Phys., 16, 3413-3432, https://doi.org/10.5194/acp-16-3413-2016, 2016.

Junker, C. and Liousse, C.: A global emission inventory of carbonaceous aerosol from historic records of fossil fuel and biofuel consumption for the period 1860-1997, Atmos. Chem. Phys., 8, 1195-1207, https://doi.org/10.5194/acp-8-1195-2008, 2008.

Ke, Z.: The Global Plume-rise Dataset and Its Climate Model Implement, in preparation, 2020.

Kirchstetter, T. W. and Thatcher, T. L.: Contribution of organic carbon to wood smoke particulate matter absorption of solar radiation, Atmos. Chem. Phys., 12, 6067-6072, https://doi.org/10.5194/acp-12-6067-2012, 2012.

Kirchstetter, T. W., Novakov, T., and Hobbs, P. V.: Evidence that the spectral dependence of light absorption by aerosols is affected by organic carbon, J. Geophys. Res.-Atmos., 109, D21208, https://doi.org/10.1029/2004JD004999, 2004.

Klimont, Z., Kupiainen, K., Heyes, C., Purohit, P., Cofala, J., Rafaj, P., Borken-Kleefeld, J., and Schöpp, W.: Global anthropogenic emissions of particulate matter including black carbon, Atmos. Chem. Phys., 17, 8681-8723, https://doi.org/10.5194/acp-178681-2017, 2017.

Knox, A., Evans, G. J., Brook, J. R., Yao, X., Jeong, C. H., Godri, K. J., Sabaliauskas, K., and Slowik, J. G.: Mass absorption cross-section of ambient black carbon aerosol in relation to chemical age, Aerosol Sci. Technol., 43, 522-532, https://doi.org/10.1080/02786820902777207, 2009.

Kumar, K. R., Sivakumar, V., Reddy, R., Gopal, K. R., and Adesina, A. J.: Inferring wavelength dependence of AOD and Ångström exponent over a sub-tropical station in South Africa using AERONET data: Influence of meteorology, long-range transport and curvature effect, Sci. Total Environ., 461, 397-408, https://doi.org/10.1016/j.scitotenv.2013.04.095, 2013.
Lamarque, J.-F., Bond, T. C., Eyring, V., Granier, C., Heil, A., Klimont, Z., Lee, D., Liousse, C., Mieville, A., Owen, B., Schultz, M. G., Shindell, D., Smith, S. J., Stehfest, E., Van Aardenne, J., Cooper, O. R., Kainuma, M., Mahowald, N., McConnell, J. R., Naik, V., Riahi, K., and van Vuuren, D. P.: Historical (1850-2000) gridded anthropogenic and biomass burning emissions of reactive gases and aerosols: methodology and application, Atmos. Chem. Phys., 10, 7017-7039, https://doi.org/10.5194/acp-10-7017-2010, 2010.

Laskin, J., Laskin, A., Nizkorodov, S. A., Roach, P., Eckert, P., Gilles, M. K., Wang, B., Lee, H. J., and Hu, Q.: Molecular selectivity of brown carbon chromophores, Environ. Sci. Technol., 48, 12047-12055, https://doi.org/10.1021/es503432r, 2014.

Laskin, A., Laskin, J., and Nizkorodov, S. A.: Chemistry of atmospheric brown carbon, Chem. Rev., 115, 4335-4382, https://doi.org/10.1021/cr5006167, 2015.

Lavi, A., Lin, P., Bhaduri, B., Carmieli, R., Laskin, A., and Rudich, Y.: Characterization of light-absorbing oligomers from reactions of phenolic compounds and Fe (III), ACS Earth Space Chem., 1, 637-646, https://doi.org/10.1021/acsearthspacechem.7b00099, 2017.

Lee, H. J., Aiona, P. K., Laskin, A., Laskin, J., and Nizkorodov, S. A.: Effect of solar radiation on the optical properties and molecular composition of laboratory proxies of atmospheric brown carbon, Environ. Sci. Technol., 48, 10217-10226, https://doi.org/10.1021/es502515r, 2014.

Lin, G., Penner, J. E., Flanner, M. G., Sillman, S., Xu, L., and Zhou, C.: Radiative forcing of organic aerosol in the atmosphere and on snow: Effects of SOA and brown carbon, J. Geophys. Res.-Atmos., 119, 7453-7476, https://doi.org/10.1002/2013JD021186, 2014.

Lin, P., Liu, J., Shilling, J. E., Kathmann, S. M., Laskin, J., and Laskin, A.: Molecular characterization of brown carbon (BrC) chromophores in secondary organic aerosol generated from photo-oxidation of toluene, Phys. Chem. Chem. Phys., 17, 23312-23325, https://doi.org/10.1039/C5CP02563J, 2015.

Liu, J., Fan, S., Horowitz, L. W., and Levy, H.: Evaluation of factors controlling long-range transport of black carbon to the Arctic, J. Geophys. Res.-Atmos., 116, D04307, https://doi.org/10.1029/2010JD015145, 2011.

Liu, J., Bergin, M., Guo, H., King, L., Kotra, N., Edgerton, E., and Weber, R. J.: Size-resolved measurements of brown carbon in water and methanol extracts and estimates of their contribution to ambient fine-particle light absorption, Atmos. Chem. Phys., 13, 12389-12404, https://doi.org/10.5194/acp-13-123892013, 2013.

Liu, J., Scheuer, E., Dibb, J., Ziemba, L. D., Thornhill, K., Anderson, B. E., Wisthaler, A., Mikoviny, T., Devi, J. J., and Bergin, M.: Brown carbon in the continental troposphere, Geophys. Res. Lett., 41, 2191-2195, https://doi.org/10.1002/2013GL058976, 2014.

Liu, J., Lin, P., Laskin, A., Laskin, J., Kathmann, S. M., Wise, M., Caylor, R., Imholt, F., Selimovic, V., and Shilling, J. E.: Optical properties and aging of light-absorbing secondary organic aerosol, Atmos. Chem. Phys., 16, 12815-12827, https://doi.org/10.5194/acp-16-12815-2016, 2016.

Liu, X., Easter, R. C., Ghan, S. J., Zaveri, R., Rasch, P., Shi, X., Lamarque, J.-F., Gettelman, A., Morrison, H., Vitt, F., Conley, A., Park, S., Neale, R., Hannay, C., Ekman, A. M. L., Hess, P., 
Mahowald, N., Collins, W., Iacono, M. J., Bretherton, C. S., Flanner, M. G., and Mitchell, D.: Toward a minimal representation of aerosols in climate models: description and evaluation in the Community Atmosphere Model CAM5, Geosci. Model Dev., 5, 709-739, https://doi.org/10.5194/gmd-5-709-2012, 2012.

Ma, P. L., Rasch, P. J., Wang, H., Zhang, K., Easter, R. C., Tilmes, S., Fast, J. D., Liu, X., Yoon, J. H., and Lamarque, J. F.: The role of circulation features on black carbon transport into the Arctic in the Community Atmosphere Model version 5 (CAM5), J. Geophys. Res.-Atmos., 118, 4657-4669, https://doi.org/10.1002/jgrd.50411, 2013.

Magalhães, A. C. O., Esteves da Silva, J. C., and Pinto da Silva, L. S.: Density functional theory calculation of the absorption properties of brown carbon chromophores generated by catechol heterogeneous ozonolysis, ACS Earth Space Chem., 1, 353-360, https://doi.org/10.1021/acsearthspacechem.7b00061, 2017.

McMeeking, G. R.: The optical, chemical, and physical properties of aerosols and gases emitted by the laboratory combustion of wildland fuels, Colorado State University, Fort Collins, Colorado Fall, 2008

Mlawer, E. J., Taubman, S. J., Brown, P. D., Iacono, M. J., and Clough, S. A.: Radiative transfer for inhomogeneous atmospheres: RRTM, a validated correlated-k model for the longwave, J. Geophys. Res.-Atmos., 102, 16663-16682, https://doi.org/10.1029/97JD00237, 1997.

LAADS DAAC: MODIS Terra level 3 monthly dataset, available at: https://ladsweb.modaps.eosdis.nasa.gov/archive/allData/ 61/MOD08_M3/, last access: 24 December 2019.

Morrison, H. and Gettelman, A.: A new two-moment bulk stratiform cloud microphysics scheme in the Community Atmosphere Model, version 3 (CAM3). Part I: Description and numerical tests, J. Climate, 21, 3642-3659, https://doi.org/10.1175/2008JCLI2105.1, 2008.

Nakayama, T., Matsumi, Y., Sato, K., Imamura, T., Yamazaki, A., and Uchiyama, A.: Laboratory studies on optical properties of secondary organic aerosols generated during the photooxidation of toluene and the ozonolysis of $\alpha$-pinene, J. Geophys. Res.Atmos., 115, D20204, https://doi.org/10.1029/2010JD014387, 2010.

Nakayama, T., Sato, K., Matsumi, Y., Imamura, T., Yamazaki, A., and Uchiyama, A.: Wavelength and NOx dependent complex refractive index of SOAs generated from the photooxidation of toluene, Atmos. Chem. Phys., 13, 531-545, https://doi.org/10.5194/acp-13-531-2013, 2013.

NASA: NASA DC3 data archive, available at: https://www-air.larc. nasa.gov/cgi-bin/ArcView/dc3, last access: 16 February 2020a.

NASA: NASA SEAC4RS data archive, available at: https:// www-air.larc.nasa.gov/cgi-bin/ArcView/seac4rs, last access: 16 February 2020b.

NASA: AERONET AOD measurements: available at: https:// aeronet.gsfc.nasa.gov/new_web/download_all_v3_aod.html, last access: 16 February 2020c.

Neale, R. B., Chen, C.-C., Gettelman, A., Lauritzen, P. H., Park, S., Williamson, D. L., Conley, A. J., Garcia, R., Kinnison, D., and Lamarque, J.-F.: Description of the NCAR community atmosphere model (CAM 5.0), NCAR Tech. Note NCAR/TN-486+ STR, 2010.

Nguyen, T. B., Lee, P. B., Updyke, K. M., Bones, D. L., Laskin, J., Laskin, A., and Nizkorodov, S. A.: Forma- tion of nitrogen-and sulfur-containing light-absorbing compounds accelerated by evaporation of water from secondary organic aerosols, J. Geophys. Res.-Atmos., 117, D01207, https://doi.org/10.1029/2011JD016944, 2012.

Odum, J. R., Jungkamp, T., Griffin, R. J., Forstner, H., Flagan, R. C., and Seinfeld, J. H.: Aromatics, reformulated gasoline, and atmospheric organic aerosol formation, Environ. Sci. Technol., 31, 1890-1897, https://doi.org/10.1021/es9605351, 1997.

Park, R. J., Kim, M. J., Jeong, J. I., Youn, D., and Kim, S.: A contribution of brown carbon aerosol to the aerosol light absorption and its radiative forcing in East Asia, Atmos. Environ., 44, 1414 1421, https://doi.org/10.1016/j.atmosenv.2010.01.042, 2010.

Park, S. and Bretherton, C. S.: The University of Washington shallow convection and moist turbulence schemes and their impact on climate simulations with the Community Atmosphere Model, J. Climate, 22, 3449-3469, https://doi.org/10.1175/2008JCLI2557.1, 2009.

Pillar, E. A. and Guzman, M. I.: Oxidation of substituted catechols at the air-water interface: Production of carboxylic acids, quinones, and polyphenols, Environ. Sci. Technol., 51, 49514959, https://doi.org/10.1021/acs.est.7b00232, 2017.

Pillar, E. A., Camm, R. C., and Guzman, M. I.: Catechol oxidation by ozone and hydroxyl radicals at the airwater interface, Environ. Sci. Technol., 48, 14352-14360, https://doi.org/10.1021/es504094x, 2014.

Platnick, S., King, M. D., Meyer, K. G., Wind, G., Amarasinghe, N., Marchant, B., Arnold, G. T., Zhang, Z., Hubanks, P. A., Ridgway, B., and Riedi, J.: MODIS Atmosphere L3 Monthly Product. NASA MODIS Adaptive Processing System, Goddard Space Flight Center, USA, https://doi.org/10.5067/MODIS/MOD08_M3.061, 2017

Ramanathan, V. and Carmichael, G.: Global and regional climate changes due to black carbon, Nat. Geosci., 1, 221-227, https://doi.org/10.1038/ngeo156, 2008.

Randerson, J., Chen, Y., Werf, G., Rogers, B., and Morton, D.: Global burned area and biomass burning emissions from small fires, J. Geophys. Res.-Biogeosci., 117, G04012, https://doi.org/10.1029/2012JG002128, 2012.

Richter, J. H. and Rasch, P. J.: Effects of convective momentum transport on the atmospheric circulation in the Community Atmosphere Model, version 3, J. Climate, 21, 1487-1499, https://doi.org/10.1175/2007JCLI1789.1, 2008.

Rienecker, M., Suarez, M. J., Todling, R., Bacmeister, J., Takacs, L., Liu, H., Gu, W., Sienkiewicz, M., Koster, R., Gelaro, R., Stajner, I., and Nielsen, J.: The GEOS-5 Data Assimilation SystemDocumentation of Versions 5.0.1, 5.1.0, and 5.2.0, 2008.

Saleh, R., Robinson, E. S., Tkacik, D. S., Ahern, A. T., Liu, S., Aiken, A. C., Sullivan, R. C., Presto, A. A., Dubey, M. K., and Yokelson, R. J.: Brownness of organics in aerosols from biomass burning linked to their black carbon content, Nat. Geosci., 7, 647-650, https://doi.org/10.1038/ngeo2220, 2014.

Saleh, R., Marks, M., Heo, J., Adams, P. J., Donahue, N. M., and Robinson, A. L.: Contribution of brown carbon and lensing to the direct radiative effect of carbonaceous aerosols from biomass and biofuel burning emissions. J. Geophys. Res.-Atmos., 120, 10285-10296, https://doi.org/10.1002/2015JD023697, 2015.

Sareen, N., Moussa, S. G., and McNeill, V. F.: Photochemical aging of light-absorbing secondary organic 
aerosol material, The J. Phys. Chem. A, 117, 2987-2996, https://doi.org/10.1021/jp309413j, 2013.

Schulz, M., Textor, C., Kinne, S., Balkanski, Y., Bauer, S., Berntsen, T., Berglen, T., Boucher, O., Dentener, F., Guibert, S., Isaksen, I. S. A., Iversen, T., Koch, D., Kirkevåg, A., Liu, X., Montanaro, V., Myhre, G., Penner, J. E., Pitari, G., Reddy, S., Seland, Ø., Stier, P., and Takemura, T.: Radiative forcing by aerosols as derived from the AeroCom present-day and pre-industrial simulations, Atmos. Chem. Phys., 6, 5225-5246, https://doi.org/10.5194/acp6-5225-2006, 2006.

Schuster, G. L., Dubovik, O., and Arola, A.: Remote sensing of soot carbon - Part 1: Distinguishing different absorbing aerosol species, Atmos. Chem. Phys., 16, 1565-1585, https://doi.org/10.5194/acp-16-1565-2016, 2016a.

Schuster, G. L., Dubovik, O., Arola, A., Eck, T. F., and Holben, B. N.: Remote sensing of soot carbon - Part 2: Understanding the absorption Ångström exponent, Atmos. Chem. Phys., 16, 15871602, https://doi.org/10.5194/acp-16-1587-2016, $2016 \mathrm{~b}$.

Schwarz, J., Spackman, J., Gao, R., Watts, L., Stier, P., Schulz, M., Davis, S., Wofsy, S., and Fahey, D.: Globalscale black carbon profiles observed in the remote atmosphere and compared to models, Geophys. Res. Lett., 37, L18812, https://doi.org/10.1029/2010GL044372, 2010.

Schwarz, J., Samset, B., Perring, A., Spackman, J., Gao, R., Stier, P., Schulz, M., Moore, F., Ray, E. A., and Fahey, D.: Global-scale seasonally resolved black carbon vertical profiles over the Pacific, Geophys. Res. Lett., 40, 5542-5547, https://doi.org/10.1002/2013GL057775, 2013.

Smith, J. D., Kinney, H., and Anastasio, C.: Phenolic carbonyls undergo rapid aqueous photodegradation to form lowvolatility, light-absorbing products, Atmos. Environ., 126, 3644, https://doi.org/10.1016/j.atmosenv.2015.11.035, 2016.

Stohl, A., Klimont, Z., Eckhardt, S., Kupiainen, K., Shevchenko, V. P., Kopeikin, V. M., and Novigatsky, A. N.: Black carbon in the Arctic: the underestimated role of gas flaring and residential combustion emissions, Atmos. Chem. Phys., 13, 8833-8855, https://doi.org/10.5194/acp-13-8833-2013, 2013.

Toon, O. B., Maring, H., Dibb, J., Ferrare, R., Jacob, D. J., Jensen, E. J., and Rosenlof, K. H.: Planning, implementation, and scientific goals of the Studies of Emissions and Atmospheric Composition, Clouds and Climate Coupling by Regional Surveys (SEAC4RS) field mission, J. Geophys. Res.-Atmos., 121, 49675009, https://doi.org/10.1002/2015JD024297, 2016.

Updyke, K. M., Nguyen, T. B., and Nizkorodov, S. A.: Formation of brown carbon via reactions of ammonia with secondary organic aerosols from biogenic and anthropogenic precursors, Atmos. Environ., 63, 22-31, https://doi.org/10.1016/j.atmosenv.2012.09.012, 2012.

Wang, H., Easter, R. C., Rasch, P. J., Wang, M., Liu, X., Ghan, S. J., Qian, Y., Yoon, J.-H., Ma, P.-L., and Vinoj, V.: Sensitivity of remote aerosol distributions to representation of cloud-aerosol interactions in a global climate model, Geosci. Model Dev., 6, 765-782, https://doi.org/10.5194/gmd-6-765-2013, 2013.

Wang, M., Ghan, S., Easter, R., Ovchinnikov, M., Liu, X., Kassianov, E., Qian, Y., Gustafson Jr., W. I., Larson, V. E., Schanen, D. P., Khairoutdinov, M., and Morrison, H.: The multi-scale aerosol-climate model PNNL-MMF: model description and evaluation, Geosci. Model Dev., 4, 137-168, https://doi.org/10.5194/gmd-4-137-2011, 2011.
Wang, Q., Jacob, D. J., Spackman, J. R., Perring, A. E., Schwarz, J. P., Moteki, N., Marais, E. A., Ge, C., Wang, J., and Barrett, S. R.: Global budget and radiative forcing of black carbon aerosol: Constraints from pole-to-pole (HIPPO) observations across the Pacific, J. Geophys. Res.-Atmos., 119, 195-206, https://doi.org/10.1002/2013JD020824, 2014.

Wang, X., Heald, C. L., Ridley, D. A., Schwarz, J. P., Spackman, J. R., Perring, A. E., Coe, H., Liu, D., and Clarke, A. D.: Exploiting simultaneous observational constraints on mass and absorption to estimate the global direct radiative forcing of black carbon and brown carbon, Atmos. Chem. Phys., 14, 10989-11010, https://doi.org/10.5194/acp-14-10989-2014, 2014.

Wang, X., Heald, C. L., Sedlacek, A. J., de Sá, S. S., Martin, S. T., Alexander, M. L., Watson, T. B., Aiken, A. C., Springston, S. R., and Artaxo, P.: Deriving brown carbon from multiwavelength absorption measurements: method and application to AERONET and Aethalometer observations, Atmos. Chem. Phys., 16, 12733 12752, https://doi.org/10.5194/acp-16-12733-2016, 2016.

Wang, X., Heald, C. L., Liu, J., Weber, R. J., Campuzano-Jost, P., Jimenez, J. L., Schwarz, J. P., and Perring, A. E.: Exploring the observational constraints on the simulation of brown carbon, Atmos. Chem. Phys., 18, 635-653, https://doi.org/10.5194/acp-18635-2018, 2018.

Ward, D. S., Kloster, S., Mahowald, N. M., Rogers, B. M., Randerson, J. T., and Hess, P. G.: The changing radiative forcing of fires: global model estimates for past, present and future, Atmos. Chem. Phys., 12, 10857-10886, https://doi.org/10.5194/acp-1210857-2012, 2012.

Washenfelder, R., Attwood, A., Brock, C., Guo, H., Xu, L., Weber, R., Ng, N., Allen, H., Ayres, B., and Baumann, K.: Biomass burning dominates brown carbon absorption in the rural southeastern United States, Geophys. Res. Lett., 42, 653-664, https://doi.org/10.1002/2014GL062444, 2015.

Wofsy, S. C.: HIAPER Pole-to-Pole Observations (HIPPO): finegrained, global-scale measurements of climatically important atmospheric gases and aerosols, Philos. Trans. Roy. Soc. A, 369, 2073-2086, https://doi.org/10.1098/rsta.2010.0313, 2011.

Wong, J. P. S., Nenes, A., and Weber, R. J., Changes in light absorptivity of molecular weight separated brown carbon due to photolytic aging, Environ. Sci. Technol., 51, 8414-8421, https://doi.org/10.1021/acs.est.7b01739, 2017.

Wong, J. P. S., Tsagkaraki, M., Tsiodra, I., Mihalopoulos, N., Violaki, K., Kanakidou, M., Sciare, J., Nenes, A., and Weber, R. J.: Atmospheric evolution of molecular-weight-separated brown carbon from biomass burning, Atmos. Chem. Phys., 19, 73197334, https://doi.org/10.5194/acp-19-7319-2019, 2019.

Xie, M., Hays, M. D., and Holder, A. L.: Light-absorbing organic carbon from prescribed and laboratory biomass burning and gasoline vehicle emissions, Sci. Rep., 7, 7318, https://doi.org/10.1038/s41598-017-06981-8, 2017.

Yan, C., Zheng, M., Bosch, C., Andersson, A., Desyaterik, Y., Sullivan, A. P., Collett, J. L., Zhao, B., Wang, S., and He, K.: Important fossil source contribution to brown carbon in Beijing during winter, Sci. Rep., 7, 43182, https://doi.org/10.1038/srep43182, 2017.

Yang, M., Howell, S. G., Zhuang, J., and Huebert, B. J.: Attribution of aerosol light absorption to black carbon, brown carbon, and dust in China - interpretations of atmospheric measure- 
ments during EAST-AIRE, Atmos. Chem. Phys., 9, 2035-2050, https://doi.org/10.5194/acp-9-2035-2009, 2009.

Yoshimori, M. and Broccoli, A. J.: Equilibrium response of an atmosphere-mixed layer ocean model to different radiative forcing agents: Global and zonal mean response, J. Climate, 21, 4399-4423, https://doi.org/10.1175/2008JCLI2172.1, 2008.

Yu, L., Smith, J., Laskin, A., Anastasio, C., Laskin, J., and Zhang, Q.: Chemical characterization of SOA formed from aqueousphase reactions of phenols with the triplet excited state of carbonyl and hydroxyl radical, Atmos. Chem. Phys., 14, 1380113816, https://doi.org/10.5194/acp-14-13801-2014, 2014.

Yu, L., Smith, J., Laskin, A., George, K. M., Anastasio, C., Laskin, J., Dillner, A. M., and Zhang, Q.: Molecular transformations of phenolic SOA during photochemical aging in the aqueous phase: competition among oligomerization, functionalization, and fragmentation, Atmos. Chem. Phys., 16, 4511-4527, https://doi.org/10.5194/acp-16-4511-2016, 2016.

Yu, P., Froyd, K. D., Portmann, R. W., Toon, O. B., Freitas, S. R., Bardeen, C. G., Brock, C., Fan, T., Gao, R. S., Katich, J. M., and Kupc, A.: Efficient in-cloud removal of aerosols by deep convection, Geophys. Res. Lett., 46, 1061-1069, https://doi.org/10.1029/2018GL080544, 2019.

Zhang, G. and McFarlane, N. A.: Sensitivity of climate simulations to the parameterization of cumulus convection in the Canadian Climate Centre general circulation model, Atmos.-Ocean, 33, 407-446, https://doi.org/10.1080/07055900.1995.9649539, 1995.

Zhang, Q., Streets, D. G., Carmichael, G. R., He, K. B., Huo, H., Kannari, A., Klimont, Z., Park, I. S., Reddy, S., Fu, J. S., Chen, D., Duan, L., Lei, Y., Wang, L. T., and Yao, Z. L.: Asian emissions in 2006 for the NASA INTEX-B mission, Atmos. Chem. Phys., 9, 5131-5153, https://doi.org/10.5194/acp-9-5131-2009, 2009.
Zhang, X., Lin, Y. H., Surratt, J. D., Zotter, P., Prévôt, A. S., and Weber, R. J.: Light-absorbing soluble organic aerosol in Los Angeles and Atlanta: A contrast in secondary organic aerosol, Geophys. Res. Lett., 38, L21810, https://doi.org/10.1029/2011GL049385, 2011.

Zhang, Y., Forrister, H., Liu, J., Dibb, J., Anderson, B., Schwarz, J. P., Perring, A. E., Jimenez, J. L., Campuzano-Jost, P., and Wang, Y.: Top-of-atmosphere radiative forcing affected by brown carbon in the upper troposphere, Nat. Geosci., 10, 486, https://doi.org/10.1038/ngeo2960, 2017.

Zhao, R., Lee, A. K. Y., Huang, L., Li, X., Yang, F., and Abbatt, J. P. D.: Photochemical processing of aqueous atmospheric brown carbon, Atmos. Chem. Phys., 15, 6087-6100, https://doi.org/10.5194/acp-15-6087-2015, 2015.

Zhong, M. and Jang, M.: Light absorption coefficient measurement of SOA using a UV-Visible spectrometer connected with an integrating sphere, Atmos. Environ., 45, 4263-4271, https://doi.org/10.1016/j.atmosenv.2011.04.082, 2011.

Zhong, M., Jang, M., Oliferenko, A., Pillai, G. G., and Katritzky, A. R.: The SOA formation model combined with semiempirical quantum chemistry for predicting UV-Vis absorption of secondary organic aerosols, Phys. Chem. Chem. Phys., 14, 90589066, https://doi.org/10.1039/c2cp23906j, 2012.

Zhou, Y., Xu, K. M., Sud, Y., and Betts, A.: Recent trends of the tropical hydrological cycle inferred from Global Precipitation Climatology Project and International Satellite Cloud Climatology Project data, J. Geophys. Res.-Atmos., 116, D09101, https://doi.org/10.1029/2010JD015197, 2011.

Zou, Y., Wang, Y., Ke, Z., Tian, H., Yang, J., and Liu, Y.: Development of a REgion-Specific Ecosystem Feedback Fire (RESFire) Model in the Community Earth System Model, J. Adv. Model. Earth Syst., 11, 417-445, https://doi.org/10.1029/2018MS001368, 2019. 